\title{
Late Neogene insect and other invertebrate fossils from Alaska and Arctic/Subarctic Canada
}

\author{
J.V. Matthews, Jr. ${ }^{1}$, A. Telka ${ }^{2}$, S.A. Kuzmina ${ }^{3^{*}}$ \\ ${ }^{1}$ Terrain Sciences Branch, Geological Survey of Canada, 601 Booth Street, Ottawa, Ontario, \\ Canada K1A 0E8. \\ Present address: 1 Red Maple Lane, Hubley, N.S., Canada B3Z 1 A5. \\ ${ }^{2}$ PALEOTEC Services - Quaternary and late Tertiary plant macrofossil and insect fossil analyses, \\ 1-574 Somerset St. West, Ottawa, Ontario K1R 5K2, Canada. \\ ${ }^{3}$ Laboratory of Arthropods, Borissiak Paleontological Institute, RAS, Profsoyuznaya 123, Moscow, \\ 117868 , Russia. \\ E-mails: shopudio@gmail.co; atelka@sympatico.ca;svkuz@yandex.ru \\ * corresponding author
}

ABSTRACT: This report concerns macro-remains of arthropods from Neogene sites in Alaska and northern Canada. New data from known or recently investigated localities are presented and comparisons made with faunas from equivalent latitudes in Asia and Greenland. Many of the Canadian sites belong to the Beaufort Formation, a prime source of late Tertiary plant and insect fossils. But new sites are continually being discovered and studied and among the most informative of these are several from the high terrace gravel on Ellesmere Island. One Ellesmere Island locality, known informally as the "Beaver Peat" contains spectacularly well preserved plant and arthropod fossils, and is the only Pliocene site in Arctic North America to yield a variety of vertebrate fossils. Like some of the other "keystone" localities discussed here, it promises to be important for dating and correlation as well as for documenting high Arctic climatic and environmental conditions during the Pliocene.

Arthropod fossils are becoming increasingly valuable for dating and correlation of Arctic Neogene sites. Such assemblages of fossils will ultimately prove valuable for dating and interpretation of deep scientific boreholes drilled in the Arctic. Furthermore, the Tertiary fossils discussed aid in dating Quaternary deposits in the North American Arctic, because they show how Tertiary faunas differ from those of Quaternary age. The faunas mentioned in this paper also aid in definition of former biotic gradients enhance our understanding of the history of the boreal and tundra biome. The earliest evidence for tundra is in the Pliocene at $80^{\circ} \mathrm{N}$, not in the late Miocene as some have suggested. The boreal realm of the Pliocene was qualitatively different from that of the present and much more extensive latitudinally. How to cite this article: Matthews J.V., Jr., Telka A., Kuzmina S.A. 2019. Late Neogene insect and other invertebrate fossils from Alaska and Arctic/Subarctic Canada // Invert. Zool. Vol.16. No.2. P.126-153. doi: 10.15298/invertzool.16.2.03

KEY WORDS: Arctic, Neogene, Arthropods, Insects, fossils, tundra, boreal forest. 


\title{
Поздненеогеновые насекомые и прочие беспозвоночные Аляски и арктической/ субарктической Канады
}

\author{
Дж.В. Мэттьюз ${ }^{1}$ мл., э. Телка², С.А. Кузьмина ${ }^{3}$ \\ ${ }^{I}$ Terrain Sciences Branch, Geological Survey of Canada, 601 Booth Street, Ottawa, Ontario, \\ Canada K1A OE8. \\ Present address: 1 Red Maple Lane, Hubley, N.S., Canada B3Z 1 A5. \\ ${ }^{2}$ PALEOTEC Services - Quaternary and late Tertiary plant macrofossil and insect fossil analyses, \\ 1-574 Somerset St. West, Ottawa, Ontario K1R 5K2, Canada. \\ ${ }^{3}$ Лаборатория Артропод, Палеонтологический институт им. А.А. Борисяка, Профсоюзная \\ ул., 123, 117868, Москва, Россия. \\ E-mails: shopudio@gmail.co; atelka@sympatico.ca; svkuz@yandex.ru \\ * автор для переписки
}

РЕЗЮМЕ: Рассмотрены остатки членистоногих из неогеновых местонахождений Аляски и северной Канады, представлены новые данные по давно известным и недавно изученным разрезам, сделаны сравнения с одновозрастными фаунами Северной Азии и Гренландии. Большинство канадских местонахождений относится к формации Бофорт - важного источника сведений о позднетретичной флоре и фауне. В последние годы описываются новые местонахождения, и среди них наиболее информативными являются разрезы высокой гравийной террасы острова Эллесмир. Один из этих разрезов, неформально известный как «Бобровый торф» содержит ископаемую флору и фауну членистоногих особо хорошей сохранности, это единственный плиоценовый разрез в арктической Северной Америке, где найдены различные остатки позвоночных. Подобно другим описанным здесь разрезам, он может стать важным источником данных для датирования и корреляции слоев, так же источником данных для реконструкции климата и природной среды Арктики в плиоцене.

Ископаемые членистоногие становятся все более значимыми для определения возраста и корреляции арктических неогеновых разрезов. Эти комплексы ископаемых будут обязательно использованы для корреляции и интерпретации данных глубокого бурения в Арктике. Более того, третичные ископаемые помогают в определении возраста четвертичных отложений; здесь показано, насколько третичные и четвертичные фауны отличаются друг от друга. Ископаемые фауны, рассмотренные здесь, помогают в определении природной зональности прошлого, что способствует нашему пониманию истории развития северной тайги и тундры. Самые ранние признаки тундры появляются на широте $80^{\circ} \mathrm{N}$ в плиоцене, а не в позднем миоцене, как считалось ранее. Бореальное царство в плиоцене было распространено гораздо шире в широтном направлении, чем в настоящее время и было качественно другим сообществом, отличным от современного бореального леса.

Как цитировать эту статью: Matthews J.V., Jr., Telka A., Kuzmina S.A. 2019. Late Neogene insect and other invertebrate fossils from Alaska and Arctic/Subarctic Canada // Invert. Zool. Vol.16. No.2. P.126-153. doi: 10.15298/invertzool.16.2.03

КЛЮЧЕВЫЕ СЛОВА: Арктика, неоген, членистоногие, насекомые, ископаемые, тундра, бореальный лес. 


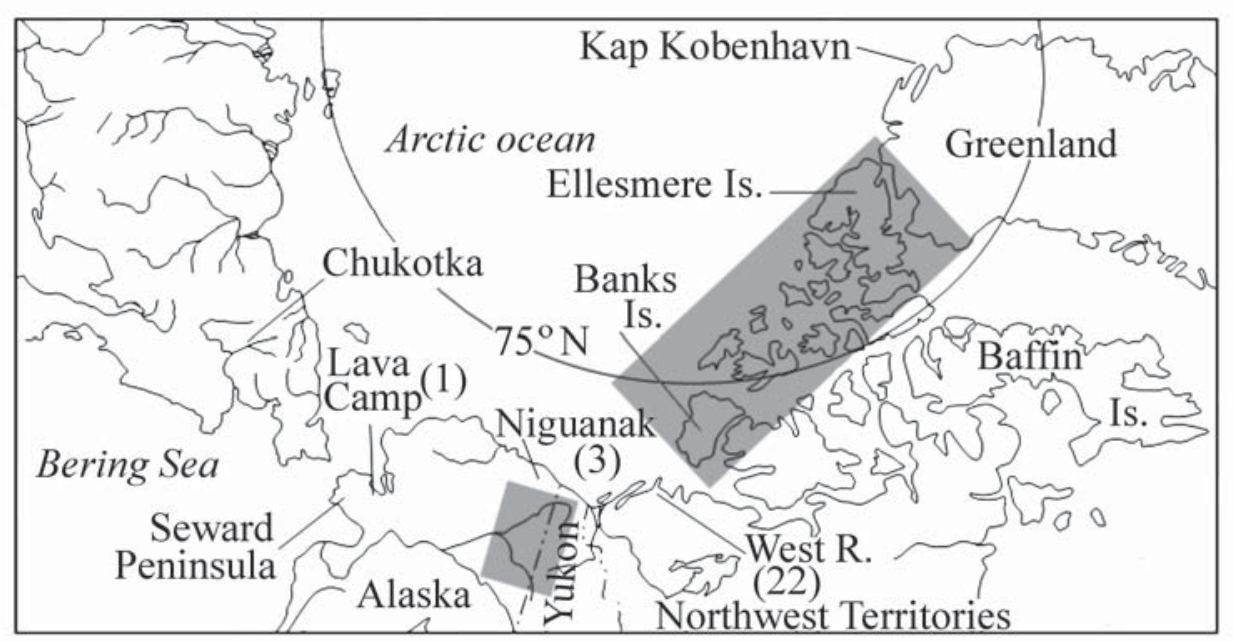

Fig. 1. Distribution of sites mentioned in the text. Shaded areas are shown in greater detail in Figs. 2 and 3. Рис. 1. Расположение местонахождений упомянутых в тексте. Серым закрашены области, изображенные подробнее на рис. 2 и 3.

\section{Introduction}

In 1987 a workshop on late Tertiary environments and biostratigraphy in the North American Arctic was held in Denver, Colorado. It was the start of a long-term program of joint studies by Canadian and American scientists. Subsequent workshops on the late Tertiary have involved Russian scientists and Russian, Canadian and United States scientists have engaged in joint field-work on both continents. The ultimate goal of these meetings and the field-work is a biostratigraphic and paleoclimatic synthesis for the Late Cenozoic in the entire circumArctic region. One of the previous reports (Matthews, Ovenden, 1990) reviewed knowledge of plant macro-remains (seeds, fruits etc.) from a number of late Tertiary sites in the Arctic/ Subarctic region of North America. Most of the research for that paper took place prior to 1988 .

Since then significant new fossil finds have occurred, both at previously studied sites and at new ones discovered. These new data alone warrant an update of Matthews \& Ovenden (1990). However, the aim in this report is to go beyond the level of discussion in the previous paper. This is possible because the database of late Tertiary macrofossils from the North Amer- ican Arctic is now large enough to attempt regional generalizations and comparisons with floras and faunas from equivalent latitudes in Russia, Greenland and Scandinavia.

What is available to us now, but not in the late 1980"s, are fossils from several independently dated "keystone" sites. Based on the data from such sites, it is now possible to develop a new correlation scheme for the Neogene of Arctic/Subarctic North America and to formulate a list of plant and arthropod fossils that have potential value for dating and correlation. But the fossils also provide new information on the evolution of Neogene climates and the history of the boreal and tundra biomes. This report discussed the arthropod part.

\section{Material and Methods}

List of fossils of insects and other arthropods is presented in the Appendix. Most specimens represent altered fragments of beetles (Coleoptera), which were identified using the synoptic reference collection at the Geological Survey of Canada, by comparison to the extensive collections in the Canadian National Collection and by consultation with various specialists. In addition to beetles, several other 
arthropod groups are represented, such as well preserved oribatid mites. Although oribatids occur in most samples of Pliocene age, only a few of them have been studied in detail, explaining the uneven representation of taxa which is evident in Appendix. The mites, chironomid (Diptera), hymenopteran and trichopteran fossils in Appendix were identified by the specialists specified at the end of that list. Some of the arthropod fossils are too poorly preserved for a definite identification, even to the generic level.

\section{Studied sites where arthoropod remains were discovered}

1. Mainland: Alaska (USA), Yukon and Northwest Territories (Canada)

\section{Lava Camp Mine (Alaska)}

The fossiliferous alluvium at Lava Camp mine on the Seward Peninsula, Alaska (Fig. 1, Appendix, site 1) is dated by an overlying 5.7 ma (late Miocene) lava (Hopkins et al., 1971). Lava Camp is the only dated Miocene site to contain both identifiable plant macro and arthropod fossils, ranking it as a keystone site for purposes of dating and correlation.

Among the plant macrofossils are fruits tentatively referred to Paliurus (Rhamnaceae). These distinctive and easily recognized fossils (see fig. 4-1 and 4-2 of Matthews \& Ovenden, 1990) may eventually prove to have quite different familial relationships; nevertheless, they have biostratigraphic significance because similar specimens occur in other floras from Arctic/ Subarctic North America and some Russian floras (Dorofeev, 1972; Baranova, Biske, 1979). Wolfe (1994) believes that the Lava Camp flora represents coastal type conifer forests. Although some of the insect fossils from Lava Camp appear to be closely related to extant tundra forms, neither the flora nor the fauna suggests tundra conditions (Laukhin, 1993a).

Lava Camp sediments were baked at the time of burial by lava. Curiously this has not seriously affected the preservation of most of the arthropod fossils and has probably favored preservation of some specimens (e.g., Micridi- um; Ptiliidae). Many of the fossils come from extinct species, a few of which have been formally described (Matthews, 1971, 1976; Leech, Matthews, 1971).

Several types of weevil fossils (Curculionidae) occur in the Lava Camp fauna. Two of them are illustrated by the heads shown in Fig. 4I and K. Both are taxa often encountered in Quaternary samples from northern Canada and Alaska. The head of Lepidophorus thulius (Kiss., 1974) (4L) is no different from that of extant species, and this means that the species has been a member of the northern fauna for nearly 6 million years - remarkable evidence of the well documented slow rate of evolution of beetles (Elias, 2010; Fikáček et al., 2011). The head of Lepidophorus sp. illustrated by Fig. 4K is slightly different from L. lineaticollis Kby., 1837, a common weevil in the northern North America. It may represent an extinct species.

Although the weevil Dryophthorus americanus Bedl., 1885 has not yet been found at Lava Camp its fossils do occur at the nearby RRR-1224 locality, which we believe to be about the same age as Lava Camp. D. americanus feeds on five-needle pines (Pinus subg. Strobus), and fossils of that type of pine, though not one now residing in North America, occur among the Lava Camp plant macrofossils.

The head of the small staphylinid beetle Gnathoryphium (Fig. 4M) is a surprising recent find among the Lava Camp collections. The only known extant species of this genus ( $G$. mandibulare Campb., 1978) occurs today at mid-elevations on Mt. Baker and Mt. Rainier in Washington State (Campbell, 1978). The fossil is smaller than heads of G. mandibulare, but it possesses several distinctive characters of the nominal species, including: (1) a broad, impunctate clypeus with an anterior raised margin; (2) small, slightly protruding eyes, only about half as long as the temples (not apparent on the foreshortened illustration of Fig. 4M); (3) parallel, moderately separated gular sutures and (4) nearly obsolete ocelli (Campbell, 1978). This fossil strongly suggests that the genus formerly occurred in the Old World, because Lava Camp is so close to the Bering Land Bridge and East 


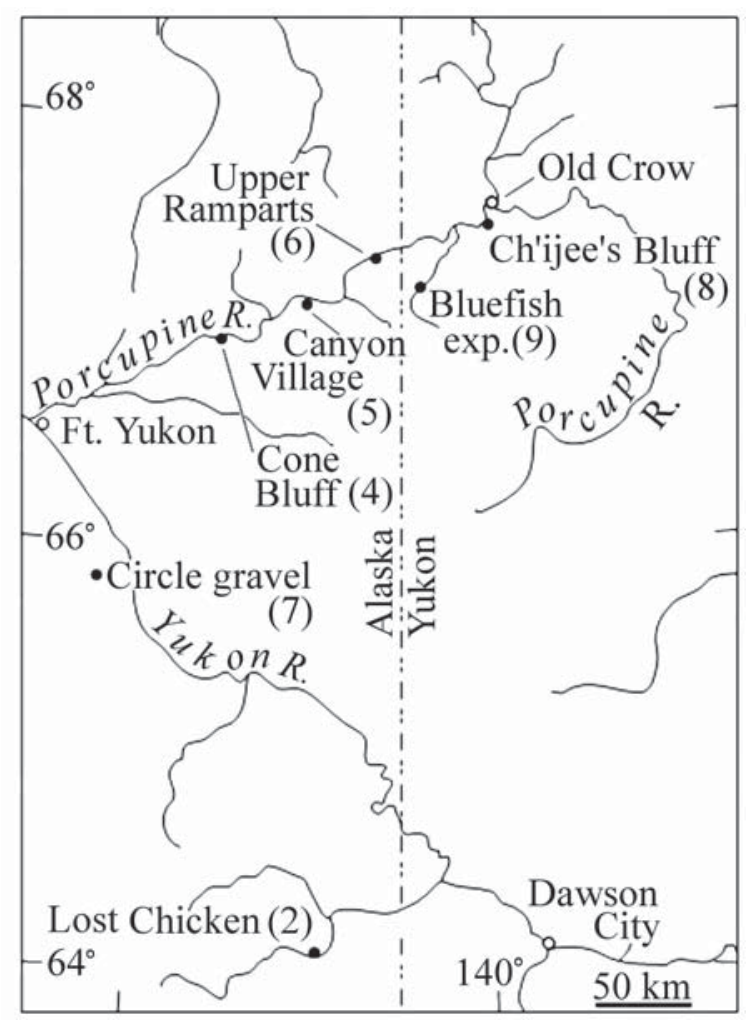

Fig. 2. Detailed site location maps of sites from interior Alaska and the Yukon.

Рис. 2. Подробная карта местонахождений внутренней Аляски и Юкона.

Asia, and the land bridge was in existence in late Miocene time (Marincovich et al., 1990).

A number of oribatid mites have recently been identified in the Lava Camp collections. They form a diverse assemblage which, at the generic level, resembles the fauna from rich, mixed deciduous-coniferous forests in Oregon (Behan-Peltier, pers. comm.). Note that this is the same type of forest posited by Wolfe (1994) on the basis of plant fossils at Lava Camp. Some of the mites, like Tritegeus or Sphodrocephus and one of the specimens referred to Propelops, do not occur today in North America. They are found in Japan, like some of the other fossils listed in Appendix (V. Behan-Peltier, pers. comm.).

\section{Lost Chicken Mine (Alaska)}

The upper pit at the Lost Chicken mine, in east central Alaska (Fig. 2, site 2, Appendix) has yielded an abundance of both arthropods and plant macrofossils (Matthews et al., 2003), fossil pollen and a few, but very significant, bones of an early horse. The horse was examined by A. Sher and V. Eisenmann, but the study was not finished. It is a keystone site for study of late Tertiary environments partly because of this diversity of its fossils, but mainly because the fossils are independently dated by their association with the Lost Chicken tephra, now dated at 2.9 ma (Matthews et al., 2003).

Like several other sites in Arctic/Subarctic North America, Lost Chicken contains seeds of the Pliocene plant Epipremnum crissum Reid et Reid, 1915 (Araceae). Even though the seeds are not directly associated with Lost Chicken tephra, they occur immediately below another tephra though to be about the same age as Lost Chicken tephra. This makes the Lost Chicken record doubly important because it one of the 
few at which Epipremnum is independently dated. Also, because the Lost Chicken Epipremnum seeds are well preserved, they must represent plants which grew at the site of deposition. In the light of the associated Lost Chicken fossils, E. crassum was a plant of rich coniferous forests, unlike its contemporary tropical relatives (Gregor, Bogner, 1984). Other sites in the Canadian Arctic reveal that it probably grew in poorly drained openings within such forests (see Ellesmere Island High Terrace deposits).

The Lost Chicken arthropod fauna contains several macrofossils of potential significance for dating and correlation. The most important of these are a few elytra superficially similar to elytra of the northern ground-beetle Asaphidion yukonense Wick., 1919. The Lost Chicken elytra (A. yukonense type A in Appendix) clearly show the bare (impunctate) patches that characterize the extant species (Fig. 4C), but the patches are less developed and elytral microsculpture better developed than in the modern species. The fossils represent an extinct species, possibly the ancestor of $A$. yukonense. As indicated below, other sites also contain fossils similar to those of A. yukonense, but display even more primitive development of the elytral patches.

Another significant arthropod taxon from Lost Chicken was designated originally as $D i$ acheila polita type A. Fossils of this extinct species, which is closely related to living $D$. polita Fald., 1835, occur at a number of other Arctic/Subarctic sites including Kap København (northern Greenland, Fig. 1). Later the species has been described as Diacheila matthewsi Böcher 1995. The Lost Chicken occurrence of $D$. matthewsi is important because the associated plant fossils strongly suggest that this extinct species was able to live within densely forested regions, unlike its modern counterpart. This species has been found also in 2003 by S. Kuzmina during short visit of the site in after conference trip.

Oribatid mites from Lost Chicken were examined by Alexander Drouk. They represent (A. Drouk, pers. comm.) an unusual fauna quite different from any that exists today in the present subarctic region. Some of the same highly ex- tralimital oribatid genera found at Lava Camp also occur at Lost Chicken. But one of the weevils from Lost Chicken originally identified as Otibazo sp. from Japan is really belong to genus Alaocybites two species of which are known from California and one, A. egorovi, Greb., 2010 from the Russian Far East. The fossil weevil from Lost Chicken is very similar to A. egorovi (Grebennikov, 2010).

The Lost Chicken flora and fauna show that eastern Alaska at the start of the Late Pliocene was characterized by rich coniferous forests. Climate was probably much less continental than at present. Some of the plants and a few of the insects have Asian affinities, not surprising when it is realized that the Bering Land Bridge was in place shortly before 3 ma and that it was likely vegetated by forests similar to those at Lost Chicken.

\section{Ch'ijee's Bluff (Yukon)}

Ch'ijee's Bluff (Fig. 2, site 8) is one of the most important exposures of Quaternary sediments in the Northern Yukon (Matthews et al., 1990b). It contains deposits of Tertiary age. Units 1 and 2 at the base of the exposure are of late Tertiary age, and part of Unit 3 may be as well. The two lower units are separated by a disconformity that may represent a significant time gap. Evidence of this is that Unit 1 is considerably more cemented than Unit 2 and contains large flag-like concretions.

Several pieces of wood from Unit 1 were identified by Wheeler \& Arnette (1994). Among them is a fragment of Abies which had been chewed by a beaver with incisor widths comparable to the modern beaver, a contrast with the beaver responsible for incisor marks at the Beaver Peat site on Ellesmere Island - see below). The wood identification adds one more conifer species (the others: five-needle pine, larch and spruce) to the group found in the northern Yukon lowlands during deposition of Unit 1. Today only spruce and rare larch occur there.

The suite of conifers from Unit 1 suggests at least a Pliocene age; and remains of the extinct plant Aracites globosa (Reid et Reid) Bennike, 1990 from the upper part of Unit 2 points to a 
similar conclusion. The top of Unit 2 also the first evidence in the sequence of permafrostrelated structures, and some of the fossil wood from near the top of the unit displays features characteristic of frost damage (Wheeler, Arnette, 1994). Even if the inception of permafrost at the site actually postdates deposition Unit 2 (i.e., the permafrost features are intrusive), these facts call for a minimum age of about 2.4-2.5 Ma (Repenning, Brouwers, 1992). As indicated above, Unit 1 may be considerably older.

Insects from the Unit 1 were not recorded by J. Matthews; but in 2015 S. Kuzmina sampled a sandy-gravel layer with wood and spruce cones which was situated $2 \mathrm{~m}$ above the river level. This layer is probably corresponded to the top of the Unit 1. A. A few insects including spruce bark beetle Scierus annectans LeC., 1876 and a weevil with elevated ridges on elytra (Fig. 4E) similar to a specimen from Beaufort Formation of Prince Patrick Is. (Fig. 4D), were found there. Such weevils have not been found in younger deposits; we are still confused to recognize the species.

\section{Bluefish Exposure (Yukon)}

Bluefish Exposure (Fig. 2, site 9) is located at Bluefish River not far from Old Crow village (Matthews, Ovenden, 1990). The lowest sample (9a in Appendix) is from lignitic zone resting on highly weathered dolomite. It contains a few poorly preserved plant macrofossils, very few unidentifiable arthropod fragments and in other ways is markedly different from the friable detrital organics with relatively well preserved fossils of sample $9 \mathrm{~b}$. Well preserved Epipremnum crassum seeds occur in abundance in sample 9b. A few other fossils of extinct plants as well as the distinctive seeds of Sambucus (elderberry) also occur at this level. However, the $9 \mathrm{~b}$ lacks any trace of five-needle pine and the arthropod assemblage has a distinctly more modern cast than the 3 ma Lost Chicken fauna. In fact, the only insect fossils which call for a pre-Quaternary age is an elytron similar to that of Notiophilus aeneus (Herbst, 1806), a species now confined to the eastern part of North America and a pronotal fragment which is similar to pronota of the extinct hydrophilid beetle Helophorus meighenensis Matth., 1976.

Collection of 2015 year (sample was taken by G. Zazula) shows that the insect assemblage yields a fragment of the extinct ground beetle Diacheila matthewsi Böcher, 1995 (Kuzmina, unpublished).

Careful paleomagnetic studies might help to establish the true age of the two Tertiary units at the Bluefish site. As indicated below, the presence of $E$. crassum could mean the sediments of $9 \mathrm{~b}$ are no younger than $3 \mathrm{ma}$, while the flora of sample 9a is similar to floras from late Miocene and early Pliocene sites. If this supposition is correct, then the Brunhes/Matuyama boundary should occur in the part of the section containing sample $9 b$.

\section{Anderson Basin, Northwest Territories}

Late Tertiary deposits occur at several localities within the Anderson Basin (Dixon et al., 1992). Some of these deposits are thought to be interglacial in age (Matthews et al., 1990a), a conclusion later refuted by Matthews \& Ovenden (1990) based on fossils found at a site near the West River (Fig. 1, site 22). However, the West River beds (Sample \#22, Appendix), resampled in 1992, are Neogene rather than Quaternary as was stated earlier. In fact they are most likely mid-Miocene (Fyles et al., 1994). Unlike other deposits of a similar age they even contain a few insect fossils, including one weevil head which seems to be intermediate between Lepidophorus lineaticollis and L. thulius (Kiss., 1974) the two species found at Lava Camp and shown in Fig. 4K and L.

Matthews and Ovenden erred when they suggested that the West River beds were the same ones thought to be of interglacial age by Mathews et al. (1990a). In 1992 the very site studied by Mathews and others was visited along with others capping the upland near the Horton River. These new samples (23 in Appendix) show that the putative interglacial locality of Mathews et al. (1990a) is certainly not as old as the West River beds, but the new samples also refute an interglacial age. They contain forest beds dominated by an extinct species of larch 
(Larix). The female cones are very similar to those of the extinct Larix groenlandi Bennike, 1990 described at Kap København in Greenland (Bennike, 1990) and now known from several other late Tertiary localities. Like $L$ groenlandi, the cones from the Plateau Cap gravels near the Horton River have somewhat longer bracts than the extant L. laricina $(\mathrm{Du}$ Roi) K. Koch, 1873.

So far the samples have yielded only small arthropod community and none appear to contain extinct species. In general the insects indicate subarctic conditions, near regional tree line.

Neogene deposits in the Horton and West River region of the Anderson Basin are abundant and form an excellent topic for future study. Like the upland or high terrace deposits on Ellesmere Island, the organics in the alluvium are evidently of several different ages, and it is possible that future studies will yield floras and insect faunas spanning much of the Neogene. A better knowledge of the biostratigraphy and age of these deposits should also help to test and improve conclusions concerning offshore deposits in the Anderson Basin (Dixon et al., 1992), thereby contributing to activities of the petroleum industry in the Beaufort Sea.

2. Islands, Northwest Territories, Arctic Archipelago, Canada

\section{Banks Island}

Ballast Brook Formation: Hills (1969) and Kuc \& Hills (1971) divided the thick sequence of gravel, sand and peat at Ballast Brook into two informal units of the Beaufort Formation. The lower one, recently re-defined as the Ballast Brook Formation (Fyles et al., 1994) is approximately $40 \mathrm{~m}$ thick and consists of a fining up sequence of sand and silt culminating in a $2 \mathrm{~m}$ thick peat bed overlain by clay (Fig. 3, site 11). Its age is thought to be mid Miocene (Fyles et al., 1994). The peat contains numerous plant macrofossils. A modern counterpart of the thick peat are Taxodium swamps on the piedmont of North Carolina and other southeastern states.
Duck Hawk Bluffs is a nearly continuous sequence of coastal bluffs extending over several kilometres. Along much of its length a complex Quaternary sequence (Vincent, 1990), rests on woody gravel and sand initially referred to the Beaufort Formation.

Mary Sachs gravel: Insect fossils from the Ballast Brook Fm. and Mary Sachs gravel (Fig. 3 , site 10) consist of rare, small fragments of elytra of the more ruggedly constructed beetles, such as weevils (Curculionidae). None of them found so far are identifiable to genus or species. Oribatid mites are also rare and poorly preserved.

\section{Beaufort Formation}

The Beaufort Formation, a wedge of sand and gravel (mostly terrestrial) on the western margin of the Canadian Arctic Archipelago, is a well known source of insect and plant macrofossils (Fyles, 1990). Until macrofossils were first examined, some workers suggested the formation was Quaternary in age. Hills (1969, 1975; Hills, Ogilvie, 1970) was the first to show that it was much older. However, some of his fossils came from deposits now excluded from the Beaufort Formation. Even so, subsequent collections of plant and insect fossils from the Beaufort Formation sensu stricto at the type locality (Fyles, 1990) show beyond a doubt that it older than the Quaternary. Ironically, study of fossils from the Beaufort Formation has provided the very knowledge needed to reliably date Quaternary age organic deposits in the Canadian Arctic.

Prince Patrick Island: The Beaufort Formation was first defined on the basis of deposits mapped on Prince Patrick Island (Fyles, 1990). Beaufort Formation samples from different sites on Prince Patrick Island contain similar assemblages of fossils; therefore, in Appendix the arthropods from individual sites or horizons at sites are shown as a single assemblage (Fig. 3, site 12). See Matthews et al. (1990a) for details. The following remarks deal with new findings or corrections of errors in the earlier treatment.

Prince Patrick Island (Green Bay beds): Green Bay fossils (12b in Appendix) come a 


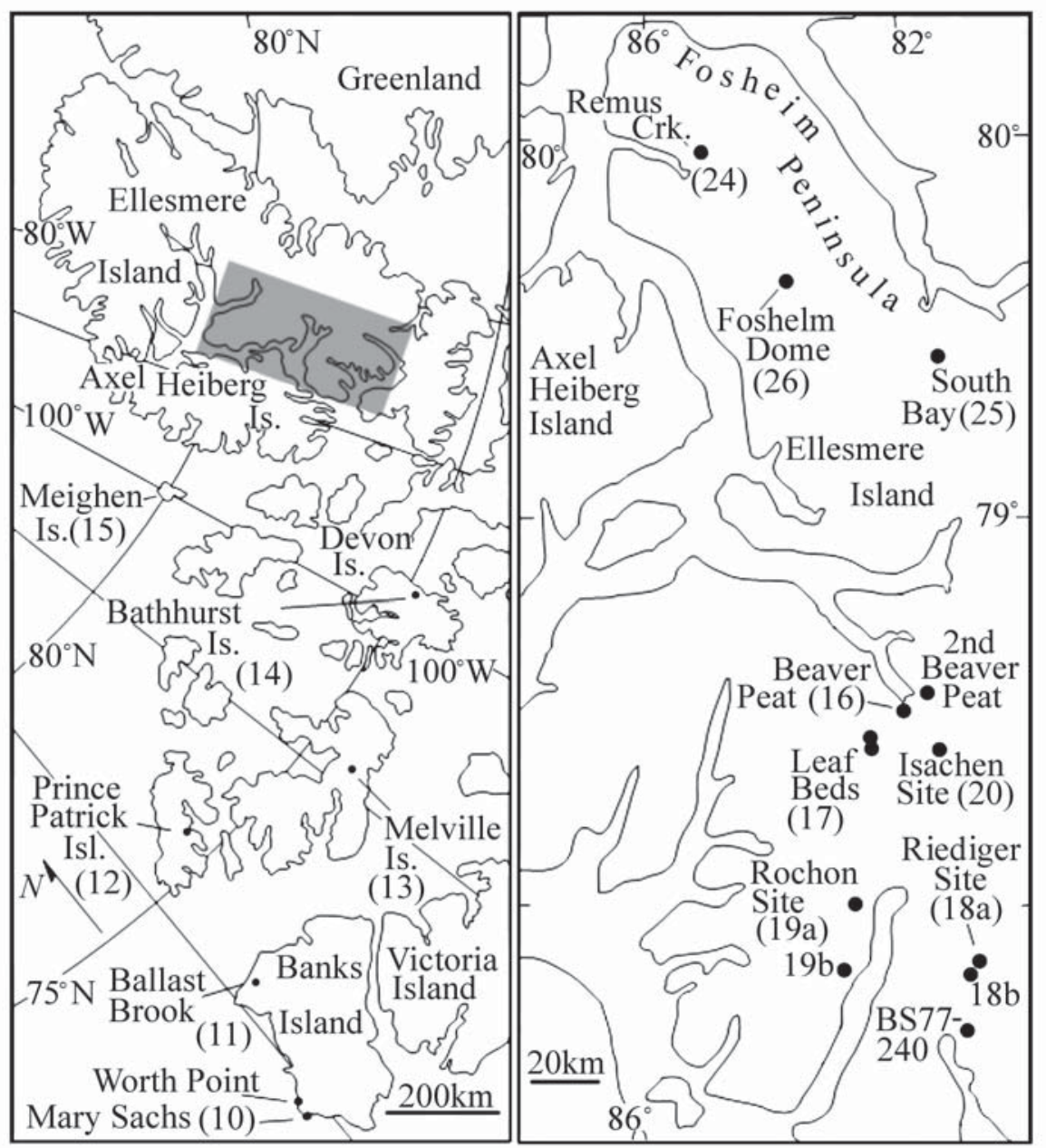

Fig. 3. Detailed site location maps of Banks Island and the Queen Elizabeth Island, Arctic Canada. Gray area on map at left indicates the region covered in the map at the right.

Рис. 3. Подробная карта местонахождений острова Банкса и островов Королевы Елизаветы, Арктическая Канада. Серым на левой карте закрашена область, изображенная подробнее на правой карте.

single site located on the east side of Prince Patrick Island (Matthews et al., 1990a). As stated previously, the site is about $40 \mathrm{~m}$ below the regional Beaufort Formation surface and is one of the few localities to contain autochthonous peat deposits (Matthews et al., 1990a). The peats are probably of Quaternary age.

In order to clarify the age of the Green Bay beds, they were re-sampled in 1991. Some new and important fossils occurred in the new samples, but the new plant fossils continued to display a low diversity of conifers and an abun- dance of the open-site plants and insects seen in earlier samples. We can only conclude that Green Bay beds were deposited at a time when larch and spruce were practically the only conifers growing on Prince Patrick Island.

Like the plant remains, arthropod fossils from Green Bay are also exceptionally well preserved. The list of taxa in Appendix differs in several minor, but important ways from the previous list (Matthews et al., 1990a). For example, on re-examination, the fossils earlier referred tentatively to the ground beetle Asaphid- 
ion cf. yukonense Wick, 1919 (Fig. 4B) are now known with certainty to represent that species. Comparison of the elytron in Fig. 4B with the elytron of a modern specimen (Fig. 4C) shows no significant differences in either microsculpture or the development of the distinctive elytral patches. The presence of the extant A. yukonense in the Green Bay beds has potential biostratigraphic implications (see below). Though not a typical tundra beetle, A. yukonense does occur on bare silt and sand areas, as for example near streams (Lindroth, 1961). Its presence warns us that the Green Bay beds do not actually represent tundra, but rather a sparsely forested region, probably near regional tree line.

Appendix includes oribatid mites (V. Behan-Peltier, pers. comm.) from the Green Bay beds. The assemblage is similar to that from
Meighen Island, though with only 13 species, not nearly as diverse. Significantly, the Green Bay beds contain fossils of Cepheus (Compactozetidae), a genus normally associated with forest habitats and one not yet recorded from Meighen Island. Notable by their absence are fossils of Achiptera (Achipteriidae), most species of which occur in well forested communities such as those represented by the Lava Camp and Lost Chicken biota. Instead the Green Bay assemblage contains mites (e.g., Trichoribates polaris Ham., 1953, Melanozetes meridianus Sellnick, 1928, Ceratoppia bipilis (Herm., 1804), C. quadridentata arctica (Ham., 1955) and Epidamaeus fortispinosus Ham., 1967) that presently live in northern taiga and low Arctic tundra. Only two (T. polaris and C. quadridentata arctica) have been collected on any of the

Formation V - Micropeplus cf. laticollis Mäk1., 1853, left elytron; Beaver Peat deposit (16), Ellesmere Is. W Hypoaspis sp. ventral view of an entire, charred individual; Beaver Peat deposit (16), Ellesmere Is. This specimen illustrates the exceptional preservation of some of the Late Tertiary fossils at various Arctic sites. X - Cepheus corae Jacot., 1928? dorsal view of a nearly complete specimen; Isachsen site (20), Ellesmere Is. Scale bar $1 \mathrm{~mm}$.

Рис. 4. Фотографии некоторых членистоногих из позднетретичных местонахождений Аляски и Арктической Канады.

А - Asaphidion yukonense type B, правое надкрылье, Балласт Брук (11), формация Бьюфорт. Видно, что оголенные пятна на надкрылье (стрелка) менее выражены чем у соседнего экземпляра. В - A. yukonense type C, левое надкрылье, Остров Принца Патрика, слои Грин Бей (12). Видно, что выраженность оголенных пятен приближается в современному типу. С - A. yukonense Wick., 1919 (левое надкрылье), современный экземпляр, показывающий нормальное состояние оголенных пятен. D - Curculionidae sp. А. левое надкрылье, остров Принца Патрика, формация Бьюфорт (12). Е - тот же вид, правое надкрылье, Чи-Чи Блафф (8), слой 1, Река Поркупайн, Юкон. F - Helophorus tuberculatus Gyll., 1808, левая часть переднеспинки. G - H. meighenensis Matth., 1976 целая переднеспинка, местонахождение Рейдигер (18a). Видны менее выраженные бугорки на центральной части переднеспинки у ископаемого жука по сравнению с современным. Н - H. tuberculatus Gyll., 1808 , современный, левое надкрылье (кружками обозначены гомологичные бугорки на каждом надкрылье). I H. meighenensis Matth., 1976 полное левое надкрылье, местонахождение Рейдигер (18а), остров Элсмир. Видны менее выраженные бугорки по сравнению с бугорками современного экземпляра. J - H. cf. meighenensis Matth., 1976 вершина левого надкрылья (немного увеличен масштаб), местонахождение Южный залив (25), остров Элсмир. Видно, что развитие бугорков у этого экземпляра немного менее выражено, чем у экземпляра (i) но возможно все еще в пределах ожидаемой изменчивости ископаемого вида. K - Lepidophorus sp., голова, вид сбоку, Лава Кэмп (1). L — L. thulius (Kiss., 1974), голова, вид сбоку, Лава Кэмп (1). Стрелкой обозначены впадины выше мелких глазных ямок, расположенные у основания головотрубки, они имеют диагностическое значение. M - Gnathoryphium sp., голова, Лава Кэмп (1). Расстояние между передней и задней частями кажется слегка укороченным из-за положения экземпляра. Стрелки показывают слабо выраженные глазки. Видно отсутствие пунктировки на наличнике и маленькие глаза. N, O — Diacheila matthewsi Böcher, 1995, эпистернум заднегруди, остров Миен, формация Бьюфорт (15b). P — Diacheila matthewsi Böcher, 1995, эпистернум заднегруди, Балласт Брук, формация Бьюфорт, (11b). Q - D. polita Fald., 1835, современный, левая часть переднеспинки экземпляра с Аляски. R - D. matthewsi Böcher, 1995, полная переднеспинка, местонахождение Рейдигер (18a), остров Элсмир. Видно более выраженная сердцевидная форма переднеспинки ископаемого жука и менее густая пунктировка. S - D. matthewsi Bцcher, 1995, Лост Чикен (2). T - Genus? (Homoptera: Aleyrodidae), карапакс, местонахождение Бобровый торф (16), остров Элсмир. U - Kalissus nitidus LeC., 1874, левое надкрылье, остров Принца Патрика (12), формация Бьюфорт. V - Micropeplus cf. laticollis Mäk1., 1853, левое надкрылье, слои Бобрового торфа (16), остров Элсмир. W - Hypoaspis sp. целый обуглившейся экземпляр, вид снизу, слои Бобрового торфа (16), остров Элсмир. Этот экземпляр показывает исключительную сохранность некоторых позднетретичных ископаемых в арктических местонахождениях. X - Cepheus corae Jacot., 1928? Вид сверху, почти целый экземпляр, местонахождение Исачсен (20), остров Элсмир. Масштабная линейка 1 мм. 


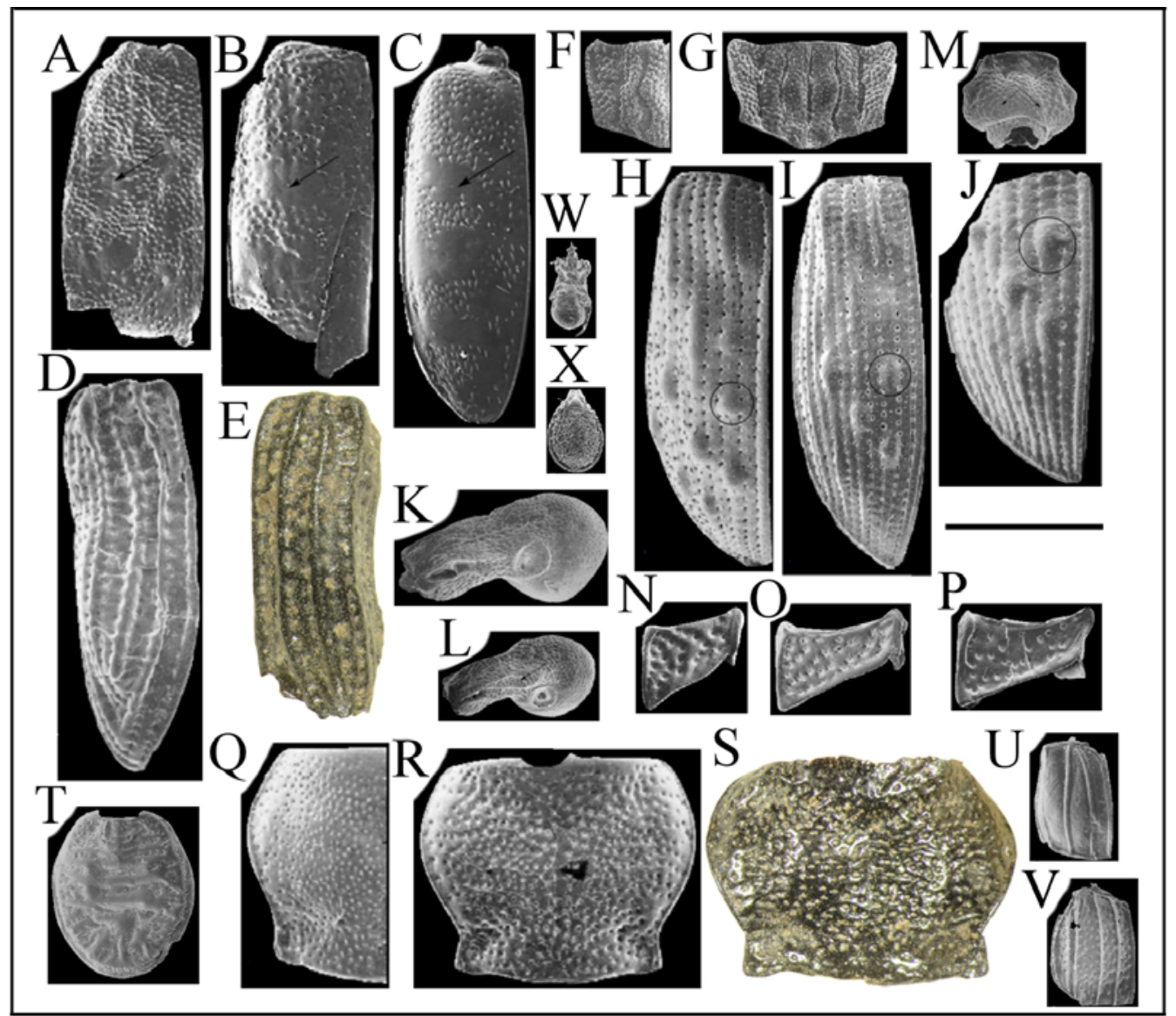

Fig. 4. SEM and optical microscope photos of selected fossil arthropods from Late Tertiary sites in Alaska and Arctic Canada.

A - Asaphidion yukonense type B, right elytron; Ballast Brook (11), Beaufort Fm. Note (arrows) the bare patches on the elytron are smaller and less extensive than on the next specimen. B - A. yukonense type $\mathrm{C}$, left elytron; Prince Patrick Is., Green Bay beds (12). Note the development of the bare patches approaches the condition in the modern specimen. C - A. yukonense Wick, 1919 (left elytron), modern specimen showing the bare patches on the elytron. D Curculionidae sp. A. left elytron; Prince Patrick Is., Beaufort Fm. (12). E - the same species, right elytron; Ch'ijee's Bluff Unit 1 (8), Porcupine R., Yukon. F - Helophorus tuberculatus Gyll., 1808 left half of pronotum. G - H. meighenensis Matth., 1976 complete pronotum; Reidiger site (18a). Note the less developed tubercles on the central part of the pronotum of the fossil as compared to the modern specimen. H - H. tuberculatus Gyll., 1808 modern, left elytron (circle indicates homologous tubercule on each elytron). I - H. meighenensis Matth., 1976 complete left elytron; Reidiger site (18a), Ellesmere Is. Note the less developed tubercles on the fossil as compared to the modern specimen. J - H. cf. meighenensis Matth., 1976 apex of left elytron (slightly expanded scale); South Bay site (25), Ellesmere Is. Note that the development of the tubercles on this specimen is slightly less than on the fossil in (i) but probably still within the expected range of variation of the fossil species. K - Lepidophorus sp. oblique view of head; Lava Camp (1); L L. thulius (Kiss., 1974) oblique view of head; Lava Camp (1). Note the diagnostic depressions (arrow) at the base of the rostrum immediately above the small eye socket. M — Gnathoryphium sp. head; Lava Camp (1). The anterior-posterior dimension is slightly foreshortened due to the position of the specimen. Arrows indicate the barely developed ocelli. Note the impunctate clypeus and the small eyes. N, O - Diacheila matthewsi Böcher, 1995; metepisternum; Meighen Island, Beaufort Fm. (15b). P — Diacheila matthewsi Böcher, 1995; metepisternum; Ballast Brook, Beaufort Fm. (11b). Q D. polita Fald., 1835, modern, left half of pronotum of a specimen from Alaska. $\mathrm{R}-$ D. matthewsi Böcher, 1995, complete pronotum; Reidiger site (18a), Ellesmere Island. Note the more cordate shape of the fossil and its less dense and deeper punctures. S - D. matthewsi; Böcher, Lost Chicken (2). T - Genus? (Homoptera: Aleyrodidae), carapace; Beaver Peat site (16), Ellesmere Is. U - Kalissus nitidus LeC., 1874, left elytron; Prince Patrick Is. (12), Beaufort 
islands of the Arctic Archipelago (V. BehanPeltier, pers. comm.). In general, then, the oribatid mites suggest a former environment and climate much like that called for by the plant and insect fossils.

The plant and arthropod macrofossils from the Green Bay site suggest a regional environment with more depauperate forests and colder climate than during deposition of the Beaufort Formation. In addition, the position of the Green Bay sediments vis-a-vis the Beaufort Formation, suggests they may be somewhat younger. Therefore, as we have done above, throughout the rest of this report and in the appendices, we refer to the Green Bay beds as a unit distinct from and almost certainly younger than the Beaufort Formation.

Banks Island: Approximately $30 \mathrm{~m}$ of sand and gravel of the Beaufort Formation unconformably overly the Ballast Brook Formation at Ballast Brook (Fig. 3). As indicated above, sediments containing typical Beaufort-type plant fossils have not yet been found above the Mary Sachs gravel at Duck Hawk Bluffs. This means that even though the Beaufort Formation is reputed to occur at many localities on the western part of the island (Vincent, 1990), Ballast Brook is the only one now known that provides paleontological information (Matthews, 1971, 1987; Fyles et al., 1994).

The upper part of the Beaufort Formation at Ballast Brook (Unit B of Fyles et al., 1994) contains numerous lenses of transported wood. The largest tree observed during 1990 field work had a diameter of $40 \mathrm{~cm}$; most are no larger than 14-20 cm. Unlike wood from the underlying Ballast Brook Formation, the Beaufort wood is well preserved and only slightly or not at all compressed. Because the deposits are alluvial in origin, much of the wood probably represents trees that occupied lowlands and flood plains, normally sites optimal for rapid tree growth. This makes it difficult to understand why growth rates were so slow, in some cases matching the growth rate of trees growing near modern tree line (Kay, 1978).

The Beaufort Formation often contains well preserved insect fossils. Appendix shows that faunas from northern Banks Island to Meighen
Island (samples 11b, 12a and 15b) are generally similar. Most differences can be attributed to the fact that Meighen Island fossils are better studied, better preserved and come from larger much large samples than the Banks Island and Prince Patrick faunas. However, there are some differences that are not so readily accounted for. A distinctive type of weevil, (Curculionidae, sp. A) occurs in practically all Prince Patrick and Ballast Brook Beaufort samples, but has yet to be found in Meighen Island deposits. Moreover, Tachyta nor any genus related to Tachys has been found on Meighen Island. And the Prince Patrick and Banks Island deposits contain specimens of an Elaphrus species that has yet to be seen in Meighen deposits.

Prince Patrick and Ballast Brook Beaufort sediments also contain distinctive elytra of a ground beetle very similar Asaphidion yukonense (Fig. 4A). Fossils of the A. yukonense type have yet to be found on Meighen Island, so we cannot yet compare specimens from all three Beaufort localities. But it is clear from Fig. 4A, that the elytron in that micrograph represents a species (Asaphidion yukonense type B in Appendix) which is at the same time similar though distinctly different from the A. yukonense specimen from the Green Bay beds (Fig. 4B). The Fig. 4A specimen displays poorer development of elytral bare patches than even the presumed extinct species (A. yukonense Type A) from the late Pliocene Lost Chicken site in Alaska.

Meighen Island: The most detailed studies of Beaufort Formation have been made on Meighen Island in the Bjaere Bay region on the western side of the island provide details on the fauna and flora as well as evidence showing the marine deposits, a unique feature of the Beaufort Formation on Meighen Island, to be about 3 ma in age (Matthews et al., unpublished).

One of the most important insect fossils, first encountered on Meighen Island but now known from other sites, is Diacheila matthewsi Böcher, 1995 (Appendix). The species is most similar to the current tundra ground-beetle $D$. polita Fald., 1835. Articulated fossils from Meighen Island show that the fossil species cannot be the ancestor of the modern species because, the 
metepisternum, the sclerite to which wing muscles attach, was smaller on the fossil D. matthewsi than in modern $D$. polita which itself has reduced flight wings. For the $D$. matthewsi fossil to be the ancestor of $D$. polita the evolution of the metepisternum would had to have undergone an improbable reversal in its reduction, implying the equally unlikely scenario of enlargement of flight wings through time (Matthews, 1979).

A number of $D$. matthewsi fossils have been found since the early Meighen Island discovery. Some of those from Prince Patrick approach the modern form, showing that the history of $D i$ acheila may be more complex than first thought. This is illustrated in Fig. 4N-P by SEM micrographs of metepisterna from different sites. The one in Fig. $4 \mathrm{~N}$ is from the articulated fossil illustrated and discussed in Matthews (1979). The specimens in 4P and $4 \mathrm{O}$ (from Meighen Island and Banks Island, respectively) have a height to length ratio similar to modern $D$. polita, but the surface punctation is significantly less dense. They are not from D. polita or the D. matthewsi, but instead probably represent another extinct species, a species with elytral and pronotal characters very much like those of the D. matthewsi. A final conclusion on the identity of some of the Diacheila specimens must await study of the specimens from all sites and discovery of other semi-articulated fossils such as the one from which the metepisternum in Fig. 4N comes; nevertheless, this example shows the type of complexities that are likely to arise as ever more fossils from different sites are studied.

A further peculiarity of the Meighen Island fauna in relation to the ground beetle Diacheila is that no fossils of the other northern Holarctic species, D. arctica Gyll., 1810, have been found. Diacheila arctica is presently a rarely collected beetle, but had been found in abundance in tundra assemblages of Quaternary age in Europe and most of its contemporary associates occur in the Meighen Island fauna. Normally such an omission might be explained as due to small sample size, but this cannot be the explanation in the case of the Meighen Island fauna.
Possibly D. arctica had not yet evolved by the start of the late Pliocene or it might not at that time have been a member of the Nearctic foresttundra and taiga fauna.

Other Insects and some of the oribatid mites from Meighen Island display biogeographical affinities similar to those shown by plants, e.g., many taxa that appear closely related to present day subarctic and low arctic tundra species with an admixture of a few whose extant relatives occur now only in eastern North America or in east Asia. In other words, the Meighen Island flora and fauna represent what was probably the northern fringe of a Late Pliocene dispersal corridor stretching from deep in eastern North America across the Bering Land Bridge into Asia. The character of the flora and fauna of Meighen Island enables us to predict the vegetation on the Bering land bridge that connected Asia and North America at the time and to further define the late Tertiary and early Quaternary migration options through this portal (see below).

\section{Ellesmere Island - High Terrace Deposits}

The Beaufort Formation has traditionally been recognized as the prime source of late Tertiary plant and arthropod fossils in the Canadian Arctic. But ongoing studies of the High Terrace deposits that occur on Ellesmere Island and Axel Heiberg Island (Fyles, 1989) show that there are equally rich sources of fossils from other areas of the Canadian Arctic. Like the Beaufort Formation fossils, those from the high terrace sites promise to provide information on climate and biostratigraphy. In addition because the high terrace deposits represent a time prior to significant uplift on the eastern islands of the Queen Elizabeth Group, fossils from those sites may some day yield information on regional late Tertiary tectonism. To a degree this is already the case at one site (Riediger sites - see below) where the macrofossils help to establish the age of a unit located above an angular unconformity that probably represents regional tectonic events.

A preview of the types of fossils found in the High Terrace deposits was given in Matthews \& Ovenden (1990). Here we expand that preview 
and show that insect macrofossils have much to contribute in determining the relative age of individual high terrace localities, and beyond that, in helping us to identify Quaternary organic deposits on Ellesmere Island and other parts of the Arctic Archipelago. A complete treatment of the High Terrace deposits and their fossils is in preparation by J.G. Fyles, Geological Survey of Canada.

Beaver Peat Locality: One of the most significant collection of sites in the High Terrace sequence occurs on Ellesmere Island at the south end of Strathcona Fjord (Fig. 3, site 16). There a unique deposit, informally called the "beaver peat" by Matthews \& Ovenden (1990), forms a plug of semi-autochthonous peat, compact enough to stand up as a vertical wall within the alluvial gravel. The peat and other organic detrital deposits within a kilometre of the peat locality, were first discovered and sampled by J.G. Fyles in the early 1960 s and since then have been mentioned in several recent reports, starting with Fyles, 1989.

The Beaver Peat is remarkable in part because it contains abundant, well preserved plant and insect fossils, but especially because it is, so far, the only one of the High Terrace sites to yield identifiable vertebrate remains. Several types of mammals in addition to fishes and birds are represented (C.R. Harington, pers. comm.), and, when the implications of these fossils are compared with results of ongoing paleomagnetic study of the site (R. Barendregt, pers. comm.), it should be able to determine the age of the site without relying on plant fossils. This is desirable because it removes the potential circularity of dating sites based on the content of plant or arthropod fossils. The vascular plant and arthropod assemblage from this locality is relatively diverse.

Among the arthropods is the exceptionally preserved gammasid mite shown in Fig. $4 \mathrm{~W}$ and numerous fossils of an unknown genus of white fly. Neither has ever been found at other sites, either Quaternary or Tertiary. The gammasid fossil probably owes its presence to the fact that it is charred, much like some of the unusual fossils from Lava Camp.
Although the macrofossil and arthropod assemblages from the several sites grouped as sample 16 include a few species that are now found far to the south, even south of the taiga zone, the overall composition of the flora and fauna seems to suggest a forest tundra site. Among the beetle fossils are several that are common in tundra regions, especially the groundbeetle, Carabus truncaticollis Esch., 1833, an obligate tundra inhabitant. Climate was undoubtedly much warmer than at the site today, but perhaps not much warmer than at present forest tree line. An open, tundra-like site, comprised largely of the extinct larch Larix groenlandi, is indicated by the plant fossils from the Beaver Peat itself.

While the Beaver Peat contains an abundance of beaver-chewed wood, it is not High Terrace site where such specimens occur. Another one (Fig. 3) is located to the northeast of the Beaver Pond site. Its fossils have only been studied in a cursory fashion, but they seem to suggest an environment and age similar to the Beaver Peat deposits.

Leaf Beds: Well preserved fossil leaves of dicotyledonous plants occur very rarely in late Tertiary peats from Ellesmere Island and other Arctic sites. In detrital and alluvial deposits they are even rarer because the depositional milieu does not favour intact preservation. A spectacular exception is the site here termed the "Leaf Beds" (FG93-10a; sample 17 in Appendix; Fig. 3 , site 17) where excellently preserved leaves occur in finely bedded sands. The Leaf Beds site provides a unique opportunity for future research.

Riediger Site and vicinity: Another important locality in the High Terrace sequence is known informally as the Riediger site (Fig. 3, site $18 \mathrm{a}-\mathrm{b}$ ), after the senior author of a previous report on the that sequence (Riediger et al., 1984). In that report a part of the sequence was referred to the Beaufort Formation on the basis of pollen, but the macrofossils show that an overlying unit is more likely the Beaufort equivalent (J. G. Fyles, pers. comm.). Fossils listed in Appendix identified as sample 18a come from these capping deposits. Sample 18b, comes from 
a site only a few kilometres away, but contains a much different flora.

Sample 18 a actually represents a combination of fossils from several thin peat beds. They are unusually rich in plant and insect fossils.

Like the plant fossils, Riediger insect fossils also suggest a Pliocene age. Among them are several fragments representing the extinct water beetle Helophorus (Cyphelophorus) meighenensis Matth., 1979 (Fig. 4G, I), which was first described from the Beaufort Formation on Meighen Island (Matthews, 1979). There appear to be no significant differences in the development of the tubercles on the elytron of the specimen in Fig. 4I and the holotype of $H$. meighenensis However, the pronotum shown in Fig. 4G is slightly different from specimens referred to $H$. meighenensis at the type locality. For example a comparison of fig. 8b of Matthews (1979) with the specimen in Fig. 4G of this paper shows that the latter has somewhat more crowded granules on the outer interval and the submarginal groove is not nearly as broad in its anterior end. In as much as one of the trends in the evolution of the Cyphelophorus lineage appears to be opening of the submarginal and marginal grooves and isolation of the granules (Fig. 4F), the Riediger specimen could be considered to be slightly more primitive than the $H$. meighenensis pronota from Meighen Island. Many more specimens will be needed before this possibility can be confirmed or denied.

Some of the other well preserved fragments from the Riediger site represent the extinct ground-beetle Diacheila matthewsi (Fig. 4R) which occurs at other Pliocene localities in Canada and Alaska, as well as in the late Pliocene Kap København Formation in northern Greenland.

A large number of the taxa from sample 18a are types expected in a present subarctic environment, and some of them, like Pelophila borealis (Payk., 1790) live today in the same type of low Arctic meadows where Sphagnum imbricatum Hornsch. ex Russow, 1865, different Eriophorum, Hippuris and Carex chordorrhiza Ehrh. ex L.f., 1781 grow. Many of the beetles have modern distributions that straddle tree line. None represent taxa restricted to forested sites. While the exact habitat requirements of the extinct species in 18a are not known, their associates in the fauna strongly suggest that they too were Subarctic inhabitants that ranged into southern tundra regions.

The $18 \mathrm{~b}$ fossils come from a nearby site which appears to be a stratigraphic equivalent of $18 \mathrm{a}$, and hence very likely the same age. But its plant fossils suggest otherwise.

Isachsen Site: Several small samples from the Isachsen Site (Fig. 3, site 20) have yielded a collection of taxa somewhat similar to that from $18 \mathrm{~b}$ near the Riediger Site. The insect assemblage from the Isachsen site also stands apart from other faunas, because it contains taxa (some not yet identified) that have not been seen at other sites, in some cases that have not been encountered at any other late Tertiary site examined by the author (J.M.). The oribatid mite faunas have yet to be studied in detail, but one taxon, Cepheus corae Jacot., 1928 (Fig. 4X), a species of well developed woodland habitats (V. Behan-Peltier, pers. comm.), is rarely found at other High Terrace sites.

Rochon Site: Some of the Ellesmere Island sites now under study or studied in the past occupy a position below the elevation of the highest terrace sediments, suggesting that they might be younger than the typical high terrace deposits. One these (Fig. 3, BS77-240) has already been described (Blake and Matthews, 1979). Its Quaternary age is clear because it has yielded finite $14 \mathrm{C}$ dates. The fauna and flora indicate a tundra environment only slightly warmer than at present.

More difficult to interpret are faunal and floral remains (19a, Appendix) from the Rochon site near the head of Vendom Fjord (Fig. 3, site $19 \mathrm{a}-\mathrm{b})$. The locality exposes several metres of autochthonous peat and seems to be positioned at a level slightly below the regional upper terrace surface. Insect fossils are extremely well preserved and many represent taxa that are now typical of the Subarctic zone. A single spruce needle was found in one of the peats, and while in alluvial deposits such a find is not of great significance, at the Rochon site it 
is because the peats are autochthonous and the spruce needle is therefore likely to represent a tree growing in the immediate area.

None of the Rochon site insect fossils appear to represent extinct species, as is the case with the Riediger site; however, one of the ground beetles, Notiophilus aeneus (Herbst, 1806), is of a type found in other late Tertiary deposits. The fact that the Rochon deposits are autochthonous is both an advantage and a disadvantage when attempting to assess the age of the site. On the one hand, their autochthonous nature assures that all fossils found in the deposit were living in the region at the time of deposition. On the negative side, such peats do not provide as complete a picture of the regional flora and fauna that is often contained in alluvial deposits.

Rochon site peats may have formed under a climate fully as warm as during the Late Tertiary, but they lack typical Tertiary components. For example, they stand in marked contrast to a nearby high terrace site (Fig. 3, site 19b) where one of the first fossils to be recovered was a needle fragment a five-needle pine. Probably the Rochon sediments were deposited after many of the typical elements of the late Tertiary Arctic flora, as documented here, had become extinct. Because the peats were deposited at a time when spruce grew on Ellesmere Island, they are almost certainly not of Quaternary age.

Fosheim Peninsula: The Fosheim Peninsula is an area where the Geological Survey of Canada has maintained a Global Change observatory, in order to better document future climate change in the Arctic. Because any such project must be accompanied by an understanding of past climate conditions, there has been a considerable and ongoing effort to garner paleoecological and paleoenvironmental data.

Most such studies are concerned with the Holocene, but Fosheim Peninsula is also a rich repository for late Tertiary sites, the majority of them first discovered by J.G. Fyles in the 1960s.

Here we briefly touch on three sites that illustrate some of the issues discussed in conjunction with other sites from Ellesmere Island and the Beaufort Formation. Remus Creek (Fig.
3, site 24) and the South Bay (Fig. 3, site 25) contain many of the plant fossils seen in typical High Terrace sediments. Seeds of the later are especially abundant - more so than at any other site examined to date. A few seeds seem to have suffered damage from some type of boring insect.

By far the most interesting fossil from the South Bay site is the apical fragment of an Helophorus elytron (Fig. 4J). Comparison with the fossils from the Riediger site suggests that the South Bay specimen is even more primitive than $H$. meighenensis at the Riediger site. It is however, much closer to $H$. meighenensis than to the late Miocene H. coopei Matth., 1976, the probable ancestor to $H$. meighenensis (Matthews 1979). The ancestor- descendant relationship of these species will be clearer with more material; we have some doubt due to proofed evolutionary stability of the genus Helophorus (Fikáèek et al., 2011). Maybe the species have older than Pliocene origin. Anyway, the presence of the extinct species confirms the pre-Quaternary age of the South Bay site.

The insect assemblage from Remus Creek site is unusually rich. Several of the fossils (e.g., Dyschirius tridentatus group) have their present northern limit south of regional tree line; hence nearly $1000 \mathrm{~km}$ south of the Fosheim Peninsula. The Remus Creek sediments do not appear to represent an open tundra-like environment such as is implied by the Beaver Peat sediments. On this basis, we argue that the Remus Creek site must be either older or younger than the Beaver Peat and associated deposits.

The Fosheim Dome sites (Fig. 3, site 26) occur along the north wall of a small valley between Fosheim Dome and the Sawtooth mountains (J.G. Fyles, pers. comm.). The Dome sites are no younger than early Pleistocene. Lack of conifer fossils or of any insects associated with forests also means that the sites are probably not as old as Remus Creek, South Bay and others that possess the typical High Terrace fossil flora.

The region around Fosheim Dome is presently one of the warmest for that latitude in the entire Canadian Arctic. Nevertheless, most of the insect fossils from the Dome sites do not form part of the present fauna (Brodo, 1992). 
The Dome site deposits accumulated under a warmer climate than at present, but probably not one warm enough to allow growth of conifers on the Fosheim Peninsula. That tree line may not have been located too far to the south is suggested by fossils of the moss, Pleurozium schreberi (Ovenden, 1989), a species found in low Arctic tundra and Subarctic forested regions (Ovenden, 1989).

\section{Taxa biostratigraphic significance}

As more and more Arctic macrofloras and macrofaunas are documented, certain taxa are emerging as having biostratigraphic value, i.e., useful for dating and regional correlation. Plant macro and micro fossils are more important for the pre-Quaternary age. Plant indicate existing of trees including extinct or exotic for the northern regions such as Pinus subg. Strobus, Larix groenlandi, Metasequoia sp., Glyptostrobus sp., Epipremnum crassum, Aracites globosa, and others.

In contrast to plants very few insect fossils have biostratigraphic significance. Earlier, Matthews (1977a) cited a beetle those wing development had apparent chronological significance. As a result of recent work on Arctic Tertiary deposits, there now appear to be a few more such taxa:

Asaphidion: Two native species of the ground beetle Asaphidion currently live in North America. One of them, A. yukonense has an elytron devoid of striae and characterized by several shiny patches where all punctures and micro sculpture are lacking. Fossils from Lost Chicken, while obviously related to A. yukonense have less development of the distinctive elytral patches and prominent microsculpture over the whole surface. They represent either an extinct species, possibly the ancestor to $A$. yukonense

Asaphidion fossils from the Beaufort Formation on northern Banks Island represent an extinct A. yukonense-like species even more "primitive" than the Lost Chicken species. Together the two extinct species and extant $A$. yukonense appear form an evolutionary series within single lineage. If so, Asaphidion elytra have definite dating implications. For example,
Asaphidion elytral remains suggest that the Green Bay beds on Prince Patrick Island are younger than Beaufort Formation in the same area, and that the age of Lost Chicken is something between the two. Other evidence from the Green Bay beds calls for an age no younger than late Pliocene; while plants from the Beaufort Formation on Prince Patrick and Banks Island limit the maximum age to the Pliocene/Miocene boundary at about 5 ma. Thus, using the Asaphidion data, Green Bay beds are 2 to 3 million years in age, Lost Chicken is 3 ma (tephra date) and the Beaufort Formation on Banks and Prince Patrick Islands is between 3 and 5 ma.

Diacheila: Many Tertiary sites in the Beaufort Formation as well as sites in Alaska and Ellesmere Island and Greenland contain fossils of an extinct ground-beetle closely related to the modern Subarctic species Diacheila polita. Actually the fossils from some sites suggest presence of two species, one of them is extinct D. matthewsi, described from Greenland, Kap København site.

Notiophilus: It is apparent from the fossils in hand that one of the trends in evolution of Notiophilus is an increase in width of the second elytral interval. A Notiophilus specimen found near the late Miocene Lava Camp site is the most primitive form seen to date. Its second elytral interval is no wider than the others and were it not for other characters the specimen might not even be assigned to Notiophilus. Other Tertiary sites have yielded more typical $\mathrm{No}$ tiophilus elytra, but with a narrow second interval like the living eastern North American species, N. aeneus Hbst., 1806. They may represent either $N$. aeneus, or a closely related extinct species. In either case a relatively great age probably pre Quaternary — is implied, but not as old as the Lava Camp site.

Fossil elytra of Notiophilus occur at several levels of a $450 \mathrm{~m}$ Taglu borehole in the Mackenzie Delta. The lowest Notiophilus fossils from that borehole are from a level dated to the late Pliocene by other fossils and paleomagnetic data. Significantly its elytra are more like $N$. aeneus, than fossils from higher in the borehole sequence. 
Helophorus: Two extinct species of the subgenus Helophorus (Cyphelophorus) have been described from Tertiary sites (Matthews, 1976). One of them, first seen from Meighen Island $(H$. meighenensis) is morphologically similar to the single extant species in the group (H. tubercula$t u s$ ) yet clearly distinguishable by elytral characters. The other species, from Lava Camp, is drastically different from either $H$. meighenensis or H. tuberculatus. A few Cyphelophorus type fossils occur in late Tertiary assemblages from Ellesmere Island, but all of them are more closely related to $H$. meighenensis than $H$. tuberculatus, which occurs at the 2-2.5 ma Kap København site (Fig. 1, Böcher, pers. comm.). If $H$. meighenensis is the ancestor of H. tuberculatus (Matthews, 1979), then the minimum age for the Ellesmere Island sites is $2.5 \mathrm{ma}$.

Micropeplus: Two species of the tiny beetle Micropeplus (M. hopkinsi Matth., 1970 and M. hoogendorni Matth., 1970) were described on the basis of fossils from Lava Camp (Matthews, 1970). Both species are now also known from the Beaufort Formation from Northern Banks Island (Matthews, 1977b), but neither of them have been reported from the Beaufort Formation on Meighen Island. Neither have any Micropeplidae been reported from the Kap København Formation (J. Böcher, pers. comm., 1991).

There is a danger in relying too heavily on extinct species as an indication of great because when better knowledge of the modern fauna is available, they may no longer be extinct. This is the case for Micropeplus hoogendorni, which was hound in Middle Pleistocene of England (Shotton et al., 1993), in the Holocene of European Russia (Matthews, 1991), and probably the senior synonym of the recent species $M$. dokuchaevi Rjabukhin, 1991 (Elias, 2010). Micropeplus hopkinsi is now known from the 3 ma Lost Chicken site, and according to data from Ch'ijee's Bluff in the northern Yukon, it also may have survived well into the late Pliocene, possible even early Quaternary.

Curculionidae: Fragments of weevils are usually present in fossil assemblages from northern regions. One of the most common beetles in Quaternary assemblages is the weevil Lepi- dophorus lineaticollis. While fossils tentatively referred to Lepidophorus occur at Arctic/Subarctic sites as old as the Miocene (e.g., West River deposits), all specimens representing $L$. lineaticollis are apparently restricted to Quaternary deposits. The species is notably absent even in the diverse insect fauna from the early Quaternary Cape Deceit Formation.

Dryophthorus americanus is another distinctive weevil whose fossils appear in several of the sites discussed here. It feeds on white pine and probably did in the past, so its fossils imply the presence of Pinus subg. Strobus, which, as stated earlier, suggest a minimum late Tertiary age.

Distinctive costate elytra (Fig. 4D) of an as yet unidentified weevil occur at Beaufort sites on Northern Banks Island and on Prince Patrick Island. It is absent from the early Late Pliocene Beaufort Formation on Meighen Island and from all of the faunas from the high terrace sediments of Ellesmere Island. Though this may be due to the latitudinal position of those sites, we also believe it possible that the species was extinct by the start of the late Pliocene.

\section{Discussion}

General: Most of the fossils are found in sediments that are Pliocene and younger in age. Those in Pliocene deposits are sometimes as abundant and as well preserved in the same manner as much younger Quaternary fossils. Most terrestrial arthropod fossils are not as buoyant as many of the fossil seeds and fruits, and this means they are less likely to be rebedded. Though insects have evolved very slowly, particularly the beetles (Coleoptera), some of the insect fossils clearly reveal evidence of evolution, in some cases apparently within a single lineage (e.g., Helophorus and Asaphidion). For some systematists such a conclusion is anathema because it violates the principles of cladistics, the most often used system of inferring ancestry on the basis of character states of living species. However, we believe that it is justifiable to suggest tentative ancestor-descendant relationships on the basis of inferred changes 
in morphological character states and then to use such transformations to suggest relative age of the fossils and the sites from which they come. Just such a hypothesis is used here to distinguish Green Bay beds from the Beaufort Formation on Prince Patrick Island.

The insect fauna of the Arctic today is extremely depauperate. Whole families of beetles that are common in the Subarctic region fail to reach even the warmest parts of Ellesmere Island (F. Brodo, unpublished GSC contract report, 1992). This fact confers great paleoenvironmental predictive power on insect fossils. For example, even a small fragment of a carabid beetle at the Hvitland site on Ellesmere Island shows that climate was warmer than at present; whereas many of the plant fossils represent taxa that occur today on northern Ellesmere Island, yielding little or no paleoenvironmental information.

Many of arthropod fossils at Arctic sites are fragments of oribatid mites. Preliminary study of such fossils has revealed some of the same paleodistributional surprises as have come from a few of the plant fossils. However, like mosses, oribatid fossils say much more about local rather than regional environments. Their abundance means that when studied the faunas can be compared in percentage fashion, more like pollen, and unlike most of the other arthropod fossils. Oribatid fossils have only been studied at a few sites and the most comprehensive effort for sites mentioned here was undertaken on Meighen Island.

When similar attention is paid to such fossils at other Tertiary sites, new knowledge of past environmental conditions will undoubtedly result. Independently dated sites (here called «keystone sites» if they also contain fossils) are still rare in the North American Arctic. But fortunately those that do exist represent critical time periods and come from key regions. Only Ellesmere Island lacks such keystone sites (Hvitland beds, as stated earlier, have few terrestrial fossils). This promises to change when the vertebrate fossils from the Beaver Peat on Strathcona Fjord are studied in detail. The Beaver Peat, because of its diversity of fossils, associated sites in the same general area, and content of mammal fossils will eventually become as important a site for understanding late Neogene Arctic environments as the Geodetic Hill fossil forests on Axel Heiberg Island have become for the Eocene (Basinger, 1991).

Trees in the High Arctic: One of the remarkable aspects of the Eocene Geodetic Hills flora with its well preserved forest beds is that it shows conclusively that trees survived and grew rapidly in a region which even in the Eocene was located near $70^{\circ} \mathrm{N}$; hence dark for six months of the year (Basinger, 1991). Even botanists are surprised by such finds because the presumed impossibility of trees surviving long dark periods that were rather warm, i.e., during which respiration could occur. Read \& Francis (1992) investigated this physiological dilemma in growth experiments with modern southern conifers and found that some species can in fact survive (and presumably adapt) to long periods of relatively warm darkness. It should also be remembered that most of the conifers found at the Eocene site were deciduous, a strategy that preadapted them to deal with the problem of prolonged warm winter darkness.

Winter climate was certainly much cooler in the Neogene than in the Paleocene, so the trees which lived in northernmost Canada as late as the Pliocene probably did not face as severe a physiological dilemma as the earlier forests. Nevertheless, it is of interest that in contrast to the present, a deciduous conifer - Larix seems to have been much more prevalent in Tertiary age forests of Arctic North America than today.

Beringia: In the parlance of most authors Beringia encompasses land areas and the presently submerged Bearing Sea/Chukchi Sea shelf between the Mackenzie River in the east and the Lena River in the west. For most of the Tertiary a land bridge existed between east Siberia and Alaska/Canada side of Beringia (Hopkins, Marincovich, 1984), foundering for awhile perhaps as early as 5 ma but certainly by about 3 ma when a flood of Pacific marine organisms moved in the Arctic Basin and from there onto the North Atlantic (Gladenkov et al., 1991; Marin- 
covich et al., 1990; Vermeij, 1991; Repenning, Brouwers, 1992). Despite the existence of a land bridge, climatic conditions on it at various times have acted as a powerful filter to intercontinental dispersal of organisms, particularly members of the forest biota. This was certainly the case during the Quaternary when periods of lower sea level and land bridge exposure were linked to climate so frigid that it precluded exchange of all arboreal plants and forest insects.

It has been suggested that cool climates and treeless vegetation also existed on the land bridge in late Miocene time (Hopkins et al., 1971). Such a filter was proposed to explain what appeared in 1971 to be distinct and long standing differences between the arboreal floras on either side of the land bridge. But fossils, particularly macrofossils from Tertiary sites in Alaska and many of the Canadian sites discussed here have overturned this argument.

First, because diverse coniferous forests existed as far north as $70^{\circ} \mathrm{N}$ during the mid Miocene, and similar forests existed at both Lava Camp and the Magadan region on the eastern and western doorsteps to the land bridge (Fig. 1, Appendix), it can no longer be argued that cool climate precluded continuity of Miocene forests between Siberia and Alaska. Furthermore, the prime reason for such a hypothesis has disappeared because macrofossil recent macrofossil studies show that the North American late Neogene Arctic/Subarctic forest flora was not all that distinct from the Asian (Baranova, Biske, 1979) forest flora. During the Miocene and probably part of the Pliocene Arctic Canada was the northeastern terminus of a completely forested link between Asia and eastern North America. For some of this time it must also have served as a route for exchange of relatively temperate plants and animals. This introduces a new suite of paleogeographic options and variables for those seeking to explain the evolution and diversity of members of the extant flora and fauna of Asia and North America.

Because northern tree line was located near $80^{\circ} \mathrm{N}$ at the start of the Late Pliocene about 3 ma, the Bering Land bridge, much further south, must also have been forested. Its forests may have resembled those which grew at the Lost Chicken site about 3 ma. But if so, the Pliocene Bering Land Bridge contained spruce and pine and maybe Abies making it the type of forests that Russian workers class as "dark coniferous". In Siberia the present northern limit of dark coniferous forests is far south of the land bridge region.

According to some workers (Laukhin, 1993b), light coniferous forest, dominated by larch, first appeared in eastern Siberia in the latter part of the early Pliocene, prior to the generally accepted time of formation of a major seaway across Beringia. Thus the breach in the land bridge, though it almost certainly interrupted continuity of forests, may only have punctuated a partitioning of the Holarctic coniferous realm that was already well underway by the late Pliocene. Evolution of the North American spruces and some of the other northern North American species that currently have no representatives in East Siberia may have started with a retreat of the dark coniferous realm to the southwest in Asia and to the east in Alaska well before a seaway developed and broke the land bridge. The arboreal floristic distinctions that started to form at this time have been perpetuated and reemphasized to the present because during all subsequent periods when the Bering Land Bridge existed, its climate was too cold for forests.

Tundra: A corollary to the above conclusions concerning Pliocene forests on the Bering Land Bridge is that tundra did not start to form in that region and at that latitude until after the land bridge had already been breached, possibly not until at least $2.5 \mathrm{ma}$ (Repenning, Brouwers, 1992). If true, this also introduces potential constraints to evolutionary hypotheses on the development of taxa now found in the present tundra flora on either end of Beringia.

But while tundra may not have existed in central Beringia 3 ma when the land bridge was finally breached, it almost certainly existed further north. The slow growth of trees on Meighen Island as well as an abundance of open ground plants such as Saxifraga oppositifolia L., 1753, 
shrub birchs, various heaths, and Oxyria is strongly suggestive of abundant open sites and climatic conditions limiting for growth of trees. Insects provide supporting evidence because among a large collection of taiga/tundra forms are a few fossils seemingly similar to modern obligate tundra species such as Amara alpina (Payk., 1790), A. glacialis (Mann, 1853), Bembidion hasti Sahlb., 1827, and several of the species in the subgenus Pterostichus (Cryobius). The presence of such putative tundra beetles on Meighen Island at 3 ma is matched by a rarity of fossils of obligate arboreal forms (e.g., bark beetles and the carabid, Dromius).

We conclude that Meighen Island contains strong circumstantial evidence of tundra-like environments at $80^{\circ} \mathrm{N}$ as early as the middle part of the Pliocene. The mouth of the Kolyma River - the region from which previous earliest evidence of lowland tundra and permafrost type climates comes - was probably still forested at 3 ma.

Contrary to statements in some reviews (Laukhin, 1993b), there exists no definite evidence from North American sites of a tundra phase at the Miocene/Pliocene boundary. Some Russian workers believe such a Messinian tundra phase is evident from pollen data in East Siberia. What we hope to have shown here is that such pollen data can potentially lead to highly erroneous conclusions when not supported by macrofossil evidence. In fact, macrofossils from both Russian and North American sites (Matthews, in prep.) strongly imply that during the Messinian (Mio/Pliocene) eastern Siberia and Alaska possessed diverse conifer forests rather than tundra.

\section{Future Studies and Needs}

Much has been learned about the evolution of Arctic environments since study of the Beaufort Formation deposits and its fossils was revived as a Geological Survey of Canada activity in the late 1970"s. The pace quickened when J.G. Fyles returned to field work in the Arctic and to many of the Neogene sites discovered by him twenty or so years earlier. Biostratigraphic and paleoenvironmental studies have also multiplied as a result of the joint USGS/GSC program on the study of late Tertiary deposits in Arctic Canada and Alaska.

Nevertheless, a number of deficiencies persist, the most glaring of these being that the study of plant and insect fossils discussed above has been carried out without reference to Old World collections and type material. When such comparisons are made, it should be possible to apply specific names to many of the fossils here identified only to the generic level.

An even better approach for comparing sites and fossils from the Eurasia and Arctic North America would be new joint field studies at key sites. Neogene sites in the northern Asia are not well studied. We can notice only three localities (Elias et al., 2006): Krestovka, Ary-Mas and Letyatkin where the pre-quaternary age of the insect assemblages has been proofed. Neogene flora including plant macrofossils is known much better, there are at least 42 localities in the northern west Siberia (Nikitin, 2006). We guess that careful sampling could allow to excavate arthropod remains from these sites.

The knowledge to result from the type of enhanced studies called for above is far from trivial. It will help us to better understand the evolution and history of environments that now typify much of Canada and other regions around the Arctic Basin. When deep sea cores are finally raised from the Arctic Ocean, the knowledge of environmental history around the Arctic basin will take on additional significance. And finally, if climate warms in the near future as a result of rising levels of greenhouse gases, any knowledge of what the Arctic/Subarctic region was like under naturally occurring warm climates should help us to predict the types of changes to occur under this type of anthropogenic forcing.

\section{Acknowledgments}

We are very grateful to J. Van der Burgh (University of Utrecht), Ole Bennike (Copenhagen), Bruce Tiffney (University of California at Santa Barbara), Alexander Drouk (retired) was of help for the identification of fossils. We 
are also indebted to our colleagues from the USGS/GSC “team” for their help, support to J. Matthews in the field and the office. In the final analysis, however, none of the work described here would have been possible without the stimulus, knowledge and samples contributed by John Fyles. Our special thank for Andrei Sher who focused efforts on cooperation of Canadian and Russian scientists. Owing to him the coauthors of this paper were introduced to each other.

\section{References}

Ager T.A., Matthews J.V., Jr., Yeend W., Wheeler E. 1994. Alluvial terrace gravels of the ancestral Yukon River near Circle, Alaska: palynological and paleobotanical evidence for a Pliocene age // Quaternary Intern. Vol.22/23. P.185-206.

Baranova J.P., Biske S.F. 1979. [Paleogene and Neogene paleoclimates of North-East Asia] // N.A. Shilo, J.A. Baranova (eds.). Kontinentalnye tretichnye tolshchi Severo-Vostoka Azii. Novosibirsk: Nauka, Siberian Branch. P.186-204 [in Russian].

Basinger J.F. 1991. The fossil forests of the Buchanan Lake Formation (Early Tertiary), Axel Heiberg Island, Canadian Arctic Archipelago: preliminary floristics and paleoclimate// Geol. Surv. Canada Bull. Vol.403. 39-65.

Bennike O. 1990. The Kap København Formation: stratigraphy and palaeobotany of a Plio-Pleistocene sequence in Peary Land, North Greenland // Meddel. Grønl. Vol.23. P.1-85.

Blake W., Jr., Matthews J.V., Jr. 1979. New data on an interglacial peat deposit near Makinson Inlet, Ellesmere Island, District of Franklin // Geol. Sur. Canada. Rep. Activ. Part B. Paper 79-1A. P.157-164.

Brodo F. 1991. Insect Survey of Hot Weather Creek; Internal Geological Survey of Canada Report in fulfillment of Contract EMR-MMd-90-0012. 16 p.

Campbell J.M. 1978. A revision of the North American Omaliinae (Coleoptera: Staphylinidae). 1. The Genera Haida Keen, Pseudohaida Hatch and Eudectoides New Genus. 2. The Tribe Coryphiini // Mem. Entomol. Soc. Canada. Vol.106. P.1-87.

Dixon J., Dietrich J.R, McNeil D.H. 1992. Upper Cretaceous to Pleistocene sequence stratigraphy of the Beaufort-Mackenzie Basin and Banks Island areas, northwest Canada // Geol. Surv. Can. Bull. Vol.407. P.1-90.

Dorofeev P.I. 1972. [Tertiary flora of the Omoloya basin] // I.T. Vassilczenko (ed.). Istoriya flory i rastitelnosti Evrazii. Moscow: Nauka. P.41-112 [in Russian].

Elias S.A. 2010. Advances in Quaternary Entomology // Dev. Quaternary Sci. Vol.12. P.1-304.
Elias S.A., Kuzmina S., Kiselev S. 2006. Late Tertiary origins of the Arctic beetle fauna // Palaeogeog. Palaeoclimat. Palaeoecol. Vol.241. P.373-392.

Fikáček M., Prokin A., Angus R.B. 2011. A long-living species of the hydrophiloid beetles: Helophorus sibiricus from the early Miocene deposits of Kartashevo (Siberia, Russia) // ZooKeys. Vol.130. P.239-254.

Fyles J.G. 1989. High terrace sediments, probably of Neogene age, west-central Ellesmere Island, Northwest Territories // Geol. Surv. Canada. Curr. Res. Part D. Paper 89-1D. P.101-104.

Fyles J.G. 1990. Beaufort Formation (Late Tertiary) as seen from Prince Patrick Island, Arctic Canada // Arctic. Vol.43 No.4. P.393-403.

Fyles J.G., Hills L.V., Matthews J.V., Jr., Barendregt R.W., Baker J., Irving E., Jetté H. 1994. Ballast Brook and Beaufort Formations (Late Tertiary) on northern Banks Island, Arctic Canada // Quaternary Intern. Vol.22/23. P.141-171.

Gibbard P.L., Head M.J. 2010. The newly-ratified definition of the Quaternary System/Period and redefinition of the Pleistocene Series/Epoch, and comparison of proposals advanced prior to formal ratification // Episodes. Vol.33. P.152-158.

Gladenkov Y.B., Barinov K.B., Basilian A.E., Cronin T.M. 1991. Stratigraphy and paleoceanography of Pliocene deposits of Karaginsky Island, Eastern Kamchatka, U.S.S.R.// Quaternary Sci. Rev. Vol.10.P.239245.

Grebennikov V.V. 2010. First Alaocybites weevil (Insecta: Coleoptera: Curculionoidea) from the Eastern Palaearctic: A new microphthalmic species and generic relationships // Arthropod Syst. Phyl. Vol.63. No.3. P.331-365.

Gregor H.J., Bogner J. 1984. Fossile Araceen Mitteleuropas und ihre rezenten Vergleichsformen // Doc. Nat. Vol.19. S.1-12.

Hills L.V. 1969. Beaufort Formation, northwestern Banks Island, District of Franklin // Geol. Surv. Canada. Rep. Activ. Part A. Paper 69-1A. P.204-207.

Hills L.V. 1975. Late Tertiary floras Arctic Canada: an interpretation // Proceedings of Circumpolar Conference on Northern Ecology. Ottawa: National Research Council of Canada. P.165-I71.

Hills L.V., Ogilvie R.T. 1970. Picea banksii n. sp., Beaufort Formation (Tertiary), northwestern Banks Island, Arctic Canada // Can. J. Bot. Vol.48. P.457-464.

Hopkins D.M., Marincovich L., Jr. 1984. Whale biogeography and the history of the Arctic Basin // Proc. Int. Symp. Arctic Whaling. Vol.8. P.8-24.

Hopkins D.M., Matthews J.V., Wolfe J.A., Silberman M.L. 1971. Pliocene flora and insect fauna from the Bering Strait region // Palaeogeogr. Palaeoclim. Palaeoecol. Vol.9. P.211-231.

Kay P.A. 1978. Dendroecology in Canada's forest-tundra transition zone // Arct. Alp. Res. Vol.10. No.1. P.133138.

Kuc M., Hills L.V. 1971. Fossil mosses, Beaufort Formation (Tertiary), northwestern Banks Island, western Canada Arctic // Can. J. Bot. Vol.49. P.1089-1094. 
Laukhin S.A. 1993a. [Climatic changes in northeast Asia during the Pliocene-Pleistocene] // Stratigr. Geolog. Korr. Vol.1. No.6. P.620-625 [in Russian]

Laukhin S.A. 1993b. Tertiary paleoclimates of Northeastern Asia // E. Planderova, M. Konzalova, Z. Kvacek, V. Sitar, P. Snopkova, D. Suballyova (eds.). Paleofloristic and Paleoclimatic Changes during Cretaceous and Tertiary, Proceedings of an International Symposium: Geologicky Ustav Dionyza Stura, Bratislava. P.171-176.

Leech R., Matthews J.V., Jr. 1971. Xysticus archaeopalpus (Arachnida: Thomisidae), a new species of crab spider from Pliocene sediments in western Alaska // Can. Entomol. Vol.103. P.1337-1340.

Marincovich L., Jr., Brouwers E.M., Hopkins D.M., McKenna M.C. 1990. Late Mesozoic and Cenozoic paleogeographic and paleoclimatic history of the Arctic Ocean Basin, based on shallow-water marine faunas and terrestrial vertebrates // A. Grantz, L. Johnson, J.F. Sweeney (eds.). The Geology of North America: The Arctic Ocean region. Vol. L. Geological Society of America. P.403-426.

Matthews J.V., Jr. 1970. Two new species of Micropeplus (Staphylinidae: Coleoptera) from the Pliocene of western Alaska with remarks on the evolution of Micropeplinae // Can. J. Zool. Vol.48. P.779-788.

Matthews J.V., Jr. 1976. Evolution of the subgenus Cyphelophorus (Genus Helophorus: Hydrophilidae, Coleoptera): description of two new fossil species and discussion of Helophorus tuberculatus Gyll. // Can. J. Zool. Vol.54. P.652-673.

Matthews J.V., Jr. 1977a. Coleoptera fossils: their possible value for dating and correlation of late Cenozoic sediments // Can. J. Earth Sci. Vol.14. P.2339-2347.

Matthews J.V., Jr. 1977b. Tertiary Coleoptera fossils from the North American Arctic // Coleopterists Bull. Vol.31. P.297-308.

Matthews J.V., Jr. 1979. Late Tertiary Carabid fossils from Alaska and the Canadian Arctic Archipelago // C.E. Ball, T.E. Irwin, D.R. Whitehead (eds.). Carabid Beetles: their Evolution, Natural History, and Classification. The Hague (Netherlands): W. Junk. P.425-445.

Matthews J.V., Jr. 1989. New information on the flora and age of the Beaufort Formation, Arctic Archipelago, and related Tertiary deposits in Alaska // Geol. Surv. Canada Curr. Res. Paper 89-1D. P.105-111.

Matthews J.V., Jr. 1991. Geological Survey of Canada Fossil Arthropod Report ARPT 91-21 (unpublished).

Matthews J.V., Jr., Ovenden L.E. 1990. Late Tertiary plant macrofossils from localities in Arctic/Subarctic North America (Alaska, Yukon and Northwest Territories): a review of the data// Arctic. Vol.43. No4. P.364-392.
Matthews J.V., Jr., Ovenden L.E., Fyles J G. 1990a. Plant and insect fossils from the late Tertiary Beaufort Formation on Prince Patrick Island, N.W.T. // C.R. Harington (ed.). Canada's Missing Dimension: Science and History in the Canadian Arctic Islands. Vol.1. Ottawa: Canadian Museum of Nature. P.105-139.

Matthews J.V., Jr., Schweger Ch.E., Janssens J.A. 1990 b. The last (Koy-Yukon) interglaciation in the northern Yukon: evidence from unit 4 at Ch'ijee's bluff, Bluefish basin // Géogr. Phys. Quat. Vol.44. P.341-352.

Matthews J.V., Jr. Westgate J.A., Ovenden L., Carte L.D., Fouch T. 2003. Stratigraphy, fossils, and age of sediments at the upper pit of the Lost Chicken gold mine: new information on the late Pliocene environment of east central Alaska // Quaternary Res. Vol.60. P.9-18.

Nikitin V.P. 2006. [Paleocarpology and stratigraphy of Paleogene and Neogene of Asiatic Russia]. Novosibirsk: Geo. 229 p. [In Russian]

Ovenden L. 1993. Late Tertiary Mosses of Ellesmere Island // Rev. Palaeobot. Palynol. Vol.79. P.121-131.

Read J., Francis J. 1992. Responses of some Southern Hemisphere tree species to a prolonged dark period and their implications for high-latitude Cretaceous and Tertiary floras // Palaeogeogr. Palaeoclim. Palaeoecol. Vol.99. P.271-290.

Repenning C.A., Brouwers E.M. 1992. Late Pliocene-Early Pleistocene ecologic changes in the Arctic Ocean borderland // U. S. Geol. Surv. Bull. Vol.2036. P.1-37.

Riediger C.L., Bustin R.M., Rouse G.E. 1984. New evidence for a chronology of the Eurekan Orogeny from south-central Ellesmere Island // Can. J. Earth Sci. Vol.21 P.1286-1295.

Shotto F.W., Keen D.H., Coope G.R., Currant A.P., Gibbard P.L., Pegler S.M., Robinson T.E. 1993. The Middle Pleistocene deposits of Waverley Wood Pit, Warwickshire, England // J. Quaternary Sci. Vol.8. No.4. P.293-325.

Vermeij G. 1991. Anatomy of an invasion: the trans-Arctic interchange // Paleobiology. Vol.17. No.3. P.281307.

Vincent J.-S. 1990. Late Tertiary and Early Pleistocene deposits and history of Banks Island, southwestern Canadian Arctic Archipelago // Arctic. Vol.43. No.4. P.339-363.

Wheeler E.A., Arnette C.G., Jr. 1994. Neogene woods from Alaska-Yukon // Quaternary Intern. Vol.22/23. P.91-102.

Wolfe J.A. 1994. An analysis of Neogene climates in Beringia // Palaeogeogr. Palaeoclim. Palaeoecol. Vol.108. P.207-216.

Responsible editor A.A. Kotov 


\section{Appendix. Insect and other animal fossils from Late Tertiary Sites in Alaska and Canada. \\ Приложение. Насекомые и прочие беспозвоночные из поздне- третичных местонахождений Аляски и Канады.}

Porifera, Demospongiae

Fam. Spongillidae

Spongillidae gen. indet.: $3,12 \mathrm{~b}, 15 \mathrm{~b}, 16,17$

Bryozoa, Phylactolaemata

Fam. Cristatellidae

Cristatella mucedo Cuvier, 1798: 3, 11b, 12a-b, 15b, $16,17,18 \mathrm{a}-\mathrm{b}, 24,26$

Fam. Plumatellidae

Plumatella sp.: $15 \mathrm{~b}$

Annelida, Oligochaeta

Fam. Lumbricidae

Lumbricidae gen. indet.: $15 \mathrm{~b}$

Arthropoda, Insecta

Ord. Odonata

Odonata gen. indet.: 2, 9b, 15b, 16

Ord. Hemiptera

Subord. Heteroptera

Fam. Tingidae

Tingidae gen. indet.: 2

Fam. Saldidae

Salda sp.: 26

Saldidae gen. indet.: 2

Heteroptera fam. indet.: $9 \mathrm{~b}$

Subord. Auchenorrhyncha

Fam. Cicadellidae

Athysanella sp.: 15b

Deltocephalus sp.: 3

Oncopsis sp.: $15 \mathrm{~b}$

Cicadellidae gen. indet.: 3, 9b, 12a-b, 15b, 16, 18b, 26

Fam. Fulgoridae

Bruchomorpha sp.: 15b

Subord. Sternorrhyncha

Fam. Psyllidae

Psyllidae gen. indet.: 2

Fam. Aphidae

Aphidae gen. indet.: $15 \mathrm{~b}$

Fam. Aleyrodidae

Aleyrodidae gen. indet.: 16

Ord. Megaloptera

Fam. Sialidae

Sialis sp.: 15b, 16

Ord. Coleoptera

Fam. Gyrinidae

Gyrinus sp.: 11b, 16, 22, 24

Fam. Trachypachidae

Trachypachus holmbergi Mnh., 1853: 15b

Trachypachus sp.: 1, 2, 11b, 12a, 15b, 16

Fam. Carabidae

Leistus sp.:1, 2

Nebria nivalis Payk., 1790: 1

Nebria sp.: 12a, 15b

Notiophilus aeneus Hbst., 1806: 1, 2, 9b, 11b, 15b, 19a

N. directus Csy., 1920: 15b
Notiophilus sp.: 2, 9b, 15b, 24, 26

Opisthius richardsoni Kby., 1837.: 15b

Pelophila cf. borealis (Payk., 1790): 1, 18a

Carabus truncaticollis Eschz., 1833: 16

C. truncaticollis type: 1

Carabus (Aulonocarabus) sp.: 1

Carabus (Hemicarabus) sp.: 12a

C. chamissonis F.-W., 1820: 15b

C. nemoralis type A: $15 \mathrm{~b}$

C. nemoralis type B: 2

C. taedatus F., 1787: 15b

C. vietinghoffi Adams, 1812: $15 \mathrm{~b}$

Carabus spp.: 11b, 12a, 15b

Blethisa catenaria Brown, 1944: 15b, 16

B. multipunctata (L., 1758): 12a, 15b

Blethisa sp.: 2, 3, 16

Diacheila matthewsi Böcher, 1995: 2

D. cf. matthewsi Böcher: 3, 9b, 11b, 12a, 15b, 16, 18a

Elaphrus cf. americanus Dej., 1831: 15b

E. clairvillei Kby., 1837: 2, 11b, 12a, 15b

E. lapponicus Gyll., 1810: 9b, 15b

E. parviceps V.D., 1925: 19a

E. cf. riparius (L., 1758): 15b

Elaphrus sp.: 11b, 12a,b, 15b, 18a

Loricera sp.: $12 \mathrm{a}$

Dyschirius globulosus (Say, 1823): 1

D. laevifasciatus Horn, 1878: 9b, 11b, 15b

D. cf. tridentatus LeC., 1852: 1, 11b, 12a, 24

D. varidens Fall, 1910: 3

Dyschirius sp.: 2, 3, 11b, 12a-b, 15b, 16

D. ruficollis Motsch., 1844: 1

Asaphidion alaskanum Wick., 1919: 9b, 11b, 12a, 15b

A. yukonense Wick., 1919: 12b

A. yukonense type A.: 2

A. yukonense type B: 11b, 12a

Asaphidion sp.: 1

Bembidion bimaculatum (Kby., 1837): 15b

B. umiatense Lth., 1963: 18a

B. grapei Gyll., 1827: 16

B. cf. grapei Gyll.: $15 \mathrm{~b}, 16$

B. hasti Sahlb., 1827: 15b

B. sordidum (Kby., 1837): 12b, 18a

B. cf. sordidum (Kby., 1837): 15b, 26

B. quadrimaculatum (L., 1761): 12b

B. dyschirinum LeC., 1861: 12a, 15b, 16

Bembidion nitidum (Kby., 1837): 11b,15b

B. nigripes (Kby., 1837): 15b

B. (Notaphus) sp.: 15b

B. planatum (LeC., 1848): 15b

B. (Plataphus) spp.: 18a

B. cf. acutifrons LeC., 1879: 1

B. pseudocautum (Lth., 1761): 1,2

B. (Trapanedoris) sp.: 12b, 15b, 16

B. levettei Csy., 1918: 11b

B. cf. balli Lindr., 1962: 11b

B. cf. lapponicum Zett., 1828: 15b 
B. (Chrysobracteon) sp.: 12a-b, 15b

B. (Plataphodes) sp.: 1, 11b, 12b, 15b, 19a

Bembidion spp.: 1, 2, 3, 9b, 15b, 16, 18a, 24, 26

Tachys sp.: 11b, 18b, 22, 24

Tachyta angulata Csy., 1918: 11b

Trechus sp.: 1, 11b, 12a

Patrobus septentrionis Dej., 1828: 1, 2

Patrobus sp.: 11b, 15b

Platidiolus vandykei Kurn., 1960: 12b, 15b

Chlaenius sp.: 2, 11b, 12b, 15b

Harpalus amputatus Say, 1830: 15b

Harpalus sp.: 2

Harpalobrachys sp.: 15b

Dromius piceus Dej., 1831: 15b

Agonum bicolor (Dej., 1828): 12a, 15b

A. consimile (Gyll., 1810): 15b, 18a

Agonum sp.: 1, 15b, 16, 18b, 24

Platynus cincticolle Say, 1823: $15 \mathrm{~b}$

$P$. decentis Say, 1823: 2

P. mannerheimi Dej., 1828: 2

Platynus sp.: 2, 15b

Poecilus (Derus) sp.: 15b

Pterostichus circulosus Lth., 1966: 15b

P. corvinus (Dej., 1828): 1

$P$. vermiculosus (Men., 1851): 1, 3, 12a, 15b, 16, 18a,

23, 26

P. puctatissimus (Rand., 1838): 2

P. (Lenapterus) sp.: 11b, 15b, 16

P. patruelis (Dej., 1831): 2

P. sublaevis (Sahlb., 1880): 15b

Stereocerus haematopus (Dej., 1831): 3, 15b, 16, 18a,

$19 \mathrm{a}$

Amara alpina (Payk., 1790): 3, 15b, 18a, 19a

A. carinata (LeC., 1847): 15b

A. hyperborea Dej., 1831: 15b

A. (Curtonotus) sp.: 12a, 15b,

A. colvillensis Lth., 1968: 15b

A. glacialis (Mann., 1853): 15b, 26

A. (Amara) sp.: 18a

Amara sp.: 12a, 19a, 26

Fam. Haliplidae

Haliplus sp.: $15 \mathrm{~b}$

Fam. Dytiscidae

Agabus bifarius (Kby., 1837): 15b, 16, 18a

Agabus sp.: 15b, 20, 16, 18a, 18b, 19a

Colymbetes sp.: 9b, 12a-b, 15b, 16, 26

Hydroporus sp.: 2, 7, 3, 12b, 15b, 16, 18a, 19a, 26

Hygrotus sp.: $12 \mathrm{a}$

Oreodytes sp.: 15b

Dytiscidae gen. indet.: 1, 2, 3, 12a, 15b, 16, 18a-b, 24

Fam. Hydrophilidae

Helophorus (Helophorus) sp.: 18a

H. meighenensis Matth., 1976: 9b, 15b, 16, 18a, 25

H. (Cyphelophorus) sp.: 12b

Helophorus spp.: 3, 9b, 12a-b, 15b, 16

Hydrobius fucipes (L.,1758): 15b

Georyssus sp.: 1, 2, 12a, 15b

Cercyon herceus Smet., 1978: 15b, 16

Cercyon sp.: 16

Hydrophilidae gen. indet.: 12b, 15b, 16, 18

Fam. Histeridae

Platysoma (Cylister) sp.: 15b

Fam. Hydraenidae

Limnebius sp.: 1, 2
Ochthebius sp.: 2, 12b, 15b, 16, 19a, 24

Fam. Ptiliidae

Micridium sp.: 1

Acrotrichus sp. 1, 16

Fam. Leiodidae

Agathidium sp.: 11b, 16

Leiodidae gen. sp.: $15 \mathrm{~b}, 16$

Fam. Silphidae

Aclypea opaca (L., 1758): 15b

Heterosilpha ramosa (Say, 1823): 15b

Phosphuga atrata (L., 1758): 15b

Silpha sp.: 11b, 12a, 16, 18a

Fam. Staphylinidae

Acidota sp.: 2, 12a, 15b, 16

Arpedium sp.: 1, 2, 15b, 16

Boreaphilus sp.: $3,12 \mathrm{a}, 12 \mathrm{~b}, 15 \mathrm{~b}$

Coryphium hyperboreum (Mäkl., 1880): 3

Coryphiini?: 1, 2, 15b, 16

Eucnecosum sp.: 15b

Gnathoryphium sp.: 1

Holoboreaphilus sp.: 15b

Micralymma sp.?: 3, 12a, 12b, 15b, 16

Olophrum boreale (Payk., 1792): 16

O. consimile (Gyll., 1810): 16

Olophrum sp. 2, 12b, 15b

Pycnoglypta lurida (Gyll., 1813): 15b

Pycnoglypta sp.: 9b, 15b, 16

Omaliinae, gen. indet.: 3, 7, 16

Kalissus nitidus (LeC., 1874:) 1, 9b, 12a

Kalissus sp. A: 15b

Micropeplus cribratus LeC., 1863: 12

M. hoogendorni Matth., 1970: 1, 11b

M. hopkinsi Matth., 1970: 1, 2, 11b

M. tesserula Curt., 1828: 1, 16, 24

Micropeplus sp.: 11b

M. laticollis Mäkl., 1853: 16

M. sculptus LeC., 1863: 11b, 12a, 15b

Pselaphinae gen. indet.: 2, 12b, 15b

Tachinus brevipennis Sahlb., 1880: 2, 3

T. jacuticus Popp., 1904: 15b

Tachinus sp.: 2, 3, 7, 11b, 12a-b, 15b, 16, 23

Tachyporus sp.: $3,12 \mathrm{~b}, 15 \mathrm{~b}, 16,18 \mathrm{a}$

Gymnusa sp.: 9b, 11b, 12a-b, 15b, 16, 18a, 19a

Aleocharinae gen. indet.: 2, 12a-b, 15b, 16, 24

Bledius sp.: 2, 3, 7, 15b, 24

Trigonurus sp.: 2

Carpelimus sp.: $15 \mathrm{~b}$

Syntomium sp.: 1

Oxytelinae, gen. indet.: $9 \mathrm{~b}$

Veraphis $\mathrm{sp} .: 1$

Scydmaeninae gen. indet.: 3, 11b, 15b, 16

Stenus sp: 1, 2, 3, 7, 9b, 11b, 12a-b, 15b, 16, 17, 19a,

22, 24, 26

Euaesthetus sp.: 2, 11b, 15b

Lathrobium sp.: 1, 2, 3, 15b, 16, 18a

Quedius cf. aenescens Mäkl., 1852: 15b

Quedius spp.: 2, 16, 18a

Fam. Scarabaeidae

Aegialia sp.: 1, 2, 3, 9b, 12a-b, 15b, 16, 18a

Aphodius sp.: 2, 15b

Fam. Scirtidae

Cyphon sp.: 2, 16

Fam. Buprestidae

Buprestidae gen. indet.: 15b 
Fam. Byrrhidae

Byrrhus sp.: 1, 3, 15b, 19a, 24

Cytilus alternatus (Say, 1825): 3, 12a-b, 18a

Morychus sp.: 1, 2, 3, 12a-b, 15b

Simplocaria sp.: 1, 2, 3, 7, 12a-b, 15b, 16, 18a

Curimopsis sp.: 12a, 15b

Byrrhidae gen. indet.: 9b, 11b

Fam. EImidae

Elmidae gen. indet.: 2, 15b

Fam. Heteroceridae

Heterocerus sp.: 3,12a

Fam. Elateridae

Berninelsonius hyperboreus (Gyll., 1827): 15b

Ctenicera sp.: 15b

Elateridae gen. indet.: $3,12 \mathrm{~b}$

Fam. Cantharidae

Podabrus sp.: 16, 18a

Fam. Bostrichidae

Bostrichidae gen. indet.: 15b

Fam. Ptinidae

Anobiinae gen. indet.: 1, 2, 3, 12b, 15b

Fam. Cucujidae

Leptophloeus sp.: $11 \mathrm{~b}$

Pediacus sp.: 2

Fam. Coccinellidae

Nephus sp.: $12 b$

Ceratomegilla sp.: $15 \mathrm{~b}$

Coccinellidae gen. indet.: 2, 12b, 16

Fam. Lathridiidae

Enicmus sp.:1

Stephostethus sp.: 15b

Lathridiidae gen. sp.: 11b, 12a-b, 16, 24

Fam. Colydiidae

Bitoma sp.: 15b

Namunaria sp.: 1

Fam. Tenebrionidae

Iphthimus sp.?: 1

Fam. Anthicidae

Onthicus sp. 15b

Anthicidae gen. indet.: 3, 16

Fam. Chrysomelidae

Donacia cf. distincta LeC., 1851: 15b

Donacia sp.: 16

Donaciinae gen. indet.: 2, 9b, 12a-b, 24

Chrysolina sp.: 1

Chrysomela sp.: $12 \mathrm{~b}$

Chrysomelidae gen. indet.: $15 \mathrm{~b}$

Fam. Brentidae

Apioninae gen. indet.: 3, 11b, 15b, 18a

Fam. Brachyceridae

Grypus equiseti (F., 1775): 3, 12a, 15b, 24

Notaris cf. bimaculatum (F., 1787): 2, 15b

Notaris sp.: 1, 2, 12a, 15b, 16, 25

Alaocybites egorovi Grebenn., 2010: 2

Erirhinus aethiops (F., 1775): 9b

Fam. Curculionidae

Dryophthorus americanus Bed., 1885: 1, 2

Ceutorhynchus sp.: 1, 2, 15b, 16

Homorosoma sp.: 16

Cylindrocopturus sp.: 16

Lepidophorus lineaticollis Kby., 1837: 2

L. pumilis Buch., 1936: 2

L. thulius (Kiss., 1974): 1, 2, 7, 9b, 12a-b, 15b, 23

Lepidophorus sp.: 1, 3, 12a, 15b, 22, 25
Otiorhynchus sp.: 2

Phyllobius sp.: $3,12 \mathrm{a}$

Connatichela sp.: 2

Hypera sp.: $15 \mathrm{~b}$

Coniocleonus sp.: $15 \mathrm{~b}$

Cleonini gen. indet:: $11 \mathrm{~b}$

Hylobius sp.: 1, 2, 11b, 15b, 24

Lepyrus spp.: 12a, 15b, 22

Pissodes sp.: 2, 15b, 24

Dorytomus sp.: $15 \mathrm{~b}$

Rhynchaenus sp.: 2, 15b, 18a, 23

Scierus sp.: 2, $15 \mathrm{~b}$

Carphoborus sp.: $11 \mathrm{~b}$

Curculionidae s. str. sp. A.: 2, 8a

Scolytinae gen. indet.: $2,11 \mathrm{~b}, 12 \mathrm{a}$

Curculionidae gen. indet.: 11b, 12a, 15b, 16, 22, 26

Ord. Trichoptera

Fam. Hydropsychidae

Arctopsyche ladogensis (Kol., 1859): 15b

Fam. Limnephilidae

Arctopora pulchella (Banks, 1908): 15b

Hydatophylax sp.: 15b

Limnephilus subcentralis Brauer, 1857: 16

Limnephilus sp.: $15 \mathrm{~b}$

Limnephilini gen. indet.: $15 \mathrm{~b}$

Fam. Calamoceratidae

Heteroplectron americanum (Walk., 1852): 15b

Fam. Molannidae

Molanna uniophila Vorh., 1909: 16

Trichoptera gen. indet.: $18 \mathrm{a}$

Ord. Diptera

Fam. Tipulidae

Tipula sp.: 12b, 15b

Tipulidae gen. indet.: 12b, 26

Fam. Chironomidae

Abiskomyia sp.: 3, 15b

Chironomus sp.?: 15b, 16, 26

Corynocera ambigua Zett., 1838: 15b

Sergentia sp.: $15 b$

Tanytarsini gen. indet.: $15 \mathrm{~b}$

Chironomidae gen. indet.: $12 b, 16,26$

Fam. Xylophagidae

Xylophagus sp.: 2, 7, 9b, 11b, 12a-b, 15b, 16, 24

Diptera gen. indet.: $3,11 \mathrm{~b}, 12 \mathrm{~b}, 16$

Ord. Hymenoptera

Subord. Symphyta

Fam. Tenthredinidae

Dolerus sp.: 16

Tenthredinidae gen. indet.: 16

Symphyta gen. indet.: $12 \mathrm{~b}, 16$

Subord. Apocrita

Superfam. Ichneumonoidae

Ichneumonoidae gen. indet.: 3, 12b, 16, 24, 26

Fam. Braconidae

Braconidae gen. indet.: 15b, 16

Fam. Ichneumonidae

Subfam. Anomalinae

Anomalinae gen. indet.: $15 \mathrm{~b}$

Subfam. Banchinae

Banchinae gen. indet.: $15 \mathrm{~b}$

Subfam. Campopleginae

Sinophorus sp.: 15b

Campopleginae gen. indet.: $15 \mathrm{~b}$

Subfam. Orthocentrinae 
Orthocentrinae gen. indet.: $15 b, 16$

Superfam. Ceraphronoidea

Fam. Megaspilidae

Conostigmus sp.: 15b, 16

Megaspilidae gen. indet.: $15 \mathrm{~b}$

Superfam. Chalcidoidea

Fam. Pteromalidae

Pteromalidae gen. indet.: $15 \mathrm{~b}$

Superfam. Diaprioidea

Fam. Diapriidae

Subfam. Belytinae

Belytinae gen. indet.: 2, 12a, 15b, 16

Diapriidae gen. indet.: $1,15 \mathrm{~b}$

Superfam. Formicoidea

Fam. Formicidae

Camponotus sp.: 18a

Formica sp.: 1, 2, 3, 16, 16b

Myrmica cf. alaskensis Whlr., 1917: 15b

Myrmica sp.: 1, 16

Formicidae gen. indet.: 2, 9b, 12a, 15b, 16, 18b, 19a, 24

Superfam. Apoidea

Superfam. Vespoidea

Vespoidea gen. indet.: $15 \mathrm{~b}$

Fam. Apidae

Bombus sp.: 16

Pyrobombus sp.: 15b

Apidae gen. indet.: 15b, 16

Arachnida, Acari

Ord. Mesostigmata

Fam. Laelapidae

Hypoaspis sp.: 15, 16

Fam. Trachytidae

Trachytes sp.?: 3

Ord. Oribatida

Fam. Chamobatidae

Chamobates sp.: 1

Fam. Ceratozetidae

Fuscozetes sp.: 1

Fam. Gustaviidae

Gustavia sp.: 1

Fam. Hermanniidae

Hermannia sp.: 1

Fam. Gymnodamaeidae

Gymnodamaeus sp.: 1

Fam. Galumnidae

Pergalumna sp.: 1

Fam. Oribatellidae

Adoribatella punctata Wooll., 1967: 2

Oribatella arctica (Thor., 1930): 2

Oribatella sp.: 1, 2

Fam. Liacaridae

Liacarus sp.: 1

Rhaphidosus carolinensis (Banks, 1906): 2

Liacaridae gen. indet.: 2

Fam. Camisiidae

Platynothrus peltifer (Koch, 1839): 15b

Fam. Compactozetidae

Cepheus corae Jac., 1928: 2, 20

Cepheus sp.: 1, 2, 3, 12b

Tritegeus major Golos. et Karp., 1984: 2

Tritegeus sp. or Sphodrocepheus sp.: 1

Fam. Damaeidae

Epidamaeus arcticolus (Ham., 1952): 15b
E. fortispinosus (Ham., 1952): 12b, 15b

Epidamaeus sp. :1, 15b

Damaeidae gen. indet.: $15 \mathrm{~b}$

Fam. Megeremaeidae

Megeremaeus ditrichosus Wool. et Higg., 1968: 1

M. keewatin Beh.-Pell., 1990: 15b

Megeremaeus sp.: 1

Fam. Eremaeidae

Eremaeus translamellatus Ham., 1952: 15b

Eremaeus sp.: 15b, 16

Proteremaeus macleani Beh.-Pell., 1982: 16

Eremaeidae gen. indet.: 2

Fam. Astegistidae

Astegistes sp.: 16

Fam. Metrioppiidae

Metrioppia helvetica Grand., 1931: 2

Ceratoppia bipilis (Her., 1804): 2, 12b, 15b

C. quadridentata (Hall., 1882): 15b, 16

C. quadridentata arctica Ham., 1955: 12b

C. rotundirostris Drouk, 1982: 2

Ceratoppia sp.: 1

Fam. Tectocepheidae

Tectocepheus velatus (Mich., 1880): 2, 15b

Fam. Hydrozetidae

Hydrozetes spp.: 2, 3, 12b, 15b, 16, 18a

Fam. Belbodamaeoidae

Belba sp.: 2

Belbodamaeoidae gen. indet.: 2

Fam. Limnozetidae

Limnozetes lustrum Beh.-Pell., 1989: 15b

Limnozetes spp.: 15b, 16

Fam. Zetomimizidae

Heterozetes sp.: 15b

Fam. Ceratozetidae

Ceratozetes inupiaq Beh.-Pell., 1986: 12b

Ceratozetes sp.: 15b

Diapterobates variabilis Ham., 1955: 2

Diapterobates sp.: $12 \mathrm{~b}$

Fuscozetes sp.: 2

Melanozetes meridianus Sell., 1928: 12b, 15b, 16

Neogymnobates sp.: 16

Oromurcia $\mathrm{sp} .:$ 12b

Sphaerozetes castaneus Ham., 1955: 2

S. piriformis (Nic., 1855): 15b

Sphaerozetes sp.: $15 \mathrm{~b}$

Trichoribates polaris Ham., 1953: 12b, 15b, 16

Trichoribates sp.: 1, 2, 12b, 15b

Ceratozetidae gen. indet.: 2

Fam. Labidostommatidae

Labidostomma sp.?: 1

Fam. Mycobatidae

Mycobates conitus Ham., 1952: 16

Mycobates sp.: 1, 2, 15b

Punctoribates hexagonus Ber., 1908: 15b, 16

P. quadrivertex Herb., 1920: 16

Punctoribates sp.: 1(?), 15b

Fam. Phenopelopidae

Eupelops occultus (Koch, 1835): 2

Eupelops sp.: 1, 2, 12b, 15b

Propelops groenlandicus (Sell., 1944): 15b

Propelops sp.: 1

Fam. Achipteriidae

Achipteria spp.: 1, 2, 15b

Anachipteria latitecta (Berl., 1908): 2 
Parachipteria nivalis (Ham., 1952): 16

Parachipteria $\mathrm{sp} .: 2$

Achipteriidae gen. indet.: 2

Fam. Oppiidae

Oppiidae gen. indet.: 1

Fam. Tegoribatidae

Lepidozetes sp.: 2,15b

Tegoribates americanus Ham., 1958: 15b

Fam. Galumnidae

Galumnidae gen. indet.: 2

Oribatida gen. indet.: $6,7,9 b, 23,24,26$

\author{
Ord. Araneae \\ Fam. Lycosidae \\ Lycosidae gen. indet.: 16, 18a, 26 \\ Fam. Thomisidae \\ Xysticus archaeopalpus Leech et Matth., 1971: 1 \\ Arthropoda, Crustacea \\ Class Branchiopoda \\ Ord. Notostraca \\ Lepiduris sp.: 3, 15b, 26 \\ Ord. Anomopoda \\ Fam. Daphniidae \\ Daphnia sp.: 2, 7, 12b, 15b, 16, 18b, 24
}

Alaska: 1 - Lava Camp, Seward Peninsula (Late Miocene: $5.7 \mathrm{Ma}$ ); 2 - Lost Chicken placer mine, Fortymile District (Late Pliocene (recently Early Pleistocene (Gibbard, Head, 2010)): $2.1 \mathrm{Ma}$ ); several localities; 3 — Niguanak site, northern Alaska (Pliocene?); 4 - Cone Bluff, Porcupine River, (Miocene/Pliocene?); 5 - Canyon Village Section, Porcupine R. (90-7 and 90-8) (Late Miocene: 5.4 Ma); 6 - Upper Ramparts of the Porcupine R. (Mid-Miocene: $16 \mathrm{Ma}$ ); 7 - Circle gravels near Circle (Pliocene?) (Ager et al., 1994). Yukon Territory: 8a - Ch'ijee's Bluff Unit 1, Porcupine R. near Old Crow (Pliocene?); 8b - Ch'ijee's Bluff Unit 2, Porcupine R. near Old Crow (Pliocene?); 9a - Bluefish sample A, Bluefish R. near Old Crow (late Miocene?); 9b - Bluefish sample B, Bluefish R. near Old Crow (late Miocene?). Northwest Territories, Queen Elizabeth Is and Banks Is.: 10 - Mary Sachs gravel at Duck Hawk Bluffs, Banks Is. (Mid-Miocene?); 11a - Ballast Brook Fm. at Ballast Brook, Banks Is. (combination of several mid-Miocene (?) local assemblages); 11b - Beaufort Fm. at Ballast Brook, Banks Is. (combination of several local assemblages including one autochthonous horizon) (Pliocene?); 12a - Beaufort Fm., Prince Patrick Is. (combination of several local assemblages) (Pliocene?); 12b - Prince Patrick Is., Green Bay beds; 13 - Melville Is., Beaufort Fm., various localities; 14 - Bathurst Is., Beaufort Fm., various localities; 15b - Beaufort Fm., Meighen Is. (combination of several local assemblages above marine unit) (3.1 Ma). Northwest Territories, Ellesmere Is.: 16 - Beaver peat and associated deposits, Strathcona Fiord (combination of several local assemblages); 17 — Leaf beds; sands with leaves near Beaver Peat site, Strathcona Fiord; $18 \mathrm{a}$ - Riediger site, near top, Ellesmere Is. $\left(77^{\circ} 51^{\prime} \mathrm{N} ; 81^{\circ} 37^{\prime} \mathrm{W}\right)$; combination of fossils from samples FG89-27e and FG89-28a; $18 \mathrm{~b}$ - FG 89-31c, organic sediments associated with log discovered within $1 \mathrm{~km}$ of the Riediger site (18a); 19a - Rochon site; FG89-22d, g; upper Vendom Fiord, $\left(79^{\circ} 39^{\prime} \mathrm{N} ; 83^{\circ} 52^{\prime} \mathrm{W}\right)$; $19 \mathrm{~b}$ - FG 89$5 \mathrm{~b}$; w of Vendom Fiord $\left(77^{\circ} 53^{\prime} \mathrm{N} ; 8^{\circ} 06^{\prime} \mathrm{W}\right) ; 20$ - Isachsen site; forest bed, high level alluvium (sample FG88-10c) and an adjacent peat with little wood (sample FG89-37c); 24 - Remus Creek site, Fosheim Peninsula; 25 — South Bay site, Fosheim Peninsula; 26 - Fosheim Dome sites, Fosheim Peninsula. Northwest Territories, Mainland: 22 - West River area, Northwest Territories coastlands (mid-Miocene?); 23 — Plateau Cap gravels locality (late Pliocene).

Аляска: 1 - Лава Кэмп, полуостров Сьюарт (поздний миоцен: $5.7 \mathrm{Ma}$ ); 2 - карьер по добыче золота Лост Чикен, округ Фотимайл (поздний плиоцен (сейчас ранний плейстоцен (Gibbard, Head, 2010)): 2.1 Ма); несколько местонахождений; 3 - местонахождение Найгуанак, северная Аляска (плиоцен?); 4 - Кон Блаф, река Поркупайн (миоцен/плиоцен?); 5 - разрез Каньон Виллидж, река Поркупайн (90-7, 90-8) (поздний миоцен: 5.4 Ма); 6 - разрезы верхнего течения реки Поркупайн (средний миоцен: 16 Ма); 7 - Гравий Цёркл около поселка Цёркл (плиоцен?) (Ager et al., 1994); Территория Юкон:8а — Чи-чи Блаф, слой 1, река Поркупайн около поселка Олд Кроу (плиоцен?); 8b - Чи-чи Блаф, слой 2, река Поркупайн около поселка Олд Кроу (плиоцен?); 9a Блюфиш образец 1 река Блюфиш около поселка Олд Кроу (поздний миоцен?); 9b - Блюфиш образец 2 река Блюфиш около поселка Олд Кроу (поздний миоцен?). Северо-западные территории, острова Королевы Елизаветы и остров Банкса: 10 - Гравий Мэри Сетч на Обрыве Болотного Луня, остров Банкса (средний миоцен?); 11a - формация Балласт Брук на хребте Балласт, остров Банкса (объединенный комплекс из нескольких средне миоценовых (?) образцов); $11 \mathrm{~b}$ - формация Балласт Брук на хребте Балласт, остров Банкса (объединенный комплекс из нескольких местных образцов включая один автохтонный горизонт) (плиоцен?); $12 \mathrm{a}$ - Остров Принца Патрика, формация Бофорт (объединенный комплекс из нескольких местных образцов) (плиоцен?); 12b - Остров Принца Патрика, слои Грин Бей; 13 - Остров Мелвилл, формация Бофорт., разные местонахождения; 14 - Остров Батерст, формация Бофорт, разные местонахождения; 15b - Остров Миен, формация Бофорт (объединенный комплекс из нескольких местных образцов выше морского горизонта) (3.1 Ма). Северо-западные территории, остров Элсмир: 16 - Бобровый торф и сопутствующие отложения, фьорд Страчкона (объединенный комплекс из нескольких местных образцов); 17 - Листовые слои, пески с листьями около местонахождения Бобровый торф, фьорд Страчкона; 18a - местонахождение Рейдигер около вершины $\left(77^{\circ} 51^{\prime} \mathrm{N} ; 81^{\circ} 37^{\prime} \mathrm{W}\right)$, объединенные комплексы из образцов FG89-27е и FG89-28a; 18b - FG 89-31с, органогенные отложения, ассоциированные с местонахождением бревен в пределах 1 км от Рейдигера (18a); 19a -

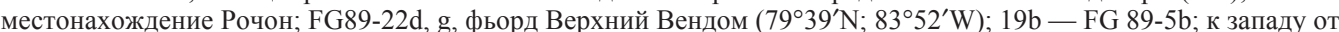
фьорда Вендом $\left(77^{\circ} 53^{\prime} \mathrm{N} ; 83^{\circ} 06^{\prime} \mathrm{W}\right) ; 20$ - местонахождение Исачсен, лесные слои, верхний горизонт аллювия (образец FG88-10c) и ископаемый торф с небольшим количеством древесины (образец FG89-37c); 24 местонахождение Ремус Крик, полуостров Фошейм; 25 - местонахождение Саус Бей полуостров Фошейм; 26 местонахождения Фошейм Дом, полуостров Фошейм. Северо-западные территории, континентальная часть: 22 - района Вест Ривер, побережье (средний миоцен?); 23 - Плато Кэп Гревий (поздний плиоцен). 